Andrews University

Digital Commons @ Andrews University

2002

\title{
A Plan To Start a Self-Suporting Evangelistic Magazine in Zimbabwe
}

Jonathan Musvosvi

Andrews University

Follow this and additional works at: https://digitalcommons.andrews.edu/dmin

Part of the Practical Theology Commons

\section{Recommended Citation}

Musvosvi, Jonathan, "A Plan To Start a Self-Suporting Evangelistic Magazine in Zimbabwe" (2002).

Professional Dissertations DMin. 588.

https://dx.doi.org/10.32597/dmin/588

https://digitalcommons.andrews.edu/dmin/588

This Project Report is brought to you for free and open access by the Graduate Research at Digital Commons @ Andrews University. It has been accepted for inclusion in Professional Dissertations DMin by an authorized administrator of Digital Commons @ Andrews University. For more information, please contact repository@andrews.edu. 
ABSTRACT

A PLAN TO START A SELF-SUPPORTING EVANGELISTIC

MAGAZINE IN ZIMBABWE

by

Jonathan Musvosvi

Chair: Jon M. Dybdahl 


\section{$65 J=G$ \\ 14}

ABSTRACT OF GRADUA

Dissertation

Andrews University

Seventh-day Adventist Theological Seminary

\section{Title: A PLAN TO START A SELF-SUPPORTING EVANGELISTIC MAGAZINE IN ZIMBABWE}

Name of researcher: Jonathan Musvosvi

Name and degree of faculty adviser: Jon DybdahI, Ph.D.

Date completed: January 1999

There is a need for an indigenous, contextualized evangelistic magazine designed specifically for the people of Zimbabwe. This dissertation looks at previous and current magazine enterprises in order to outline the implementation of a successful, self-supporting SDA magazine in Zimbabwe. The responsibilities of the editor-publisher, writers, and marketers are examined in relation to the target audience. Information on writer training is outlined in detail. Books and magazine articles on the topic of magazine publishing provided the primary source of information. Current and former magazine editors were also interviewed to provide a first-person look at the magazine 
industry. In order to be successful, the proposed magazine will need to contextualize, assign multiple roles to each member of the staff, and begin on a small scale. Also, in keeping with the example provided by James and Ellen White, the magazine project should be implemented immediately without waiting for "sufficient" resources; instead, faith must be placed in God to protect and provide for the magazine in its mission of evangelism. 


$$
\begin{aligned}
& \text { Andrews University } \\
& \text { Seventh-day Adventist Theological Seminary }
\end{aligned}
$$

A PLAN TO START A SELF-SUPPORTING EVANGELISTIC MAGAZINE IN ZIMBABWE

\author{
A Dissertation \\ Presented in Partial Fulfillment \\ of the Requirements for the Degree \\ Doctor of Ministry
}

by

Jonathan Musvosvi

August 2002 

A PLAN TO START A SELF-SUPPORTING EVANGELISTIC

MAGAZINE IN ZIMBABWE

A dissertation

presented in partial fulfillment

of the requirements for the degree

Doctor of Ministry

by

Jonathan Musvosvi

APPROVAL BY THE COMMITTEE:

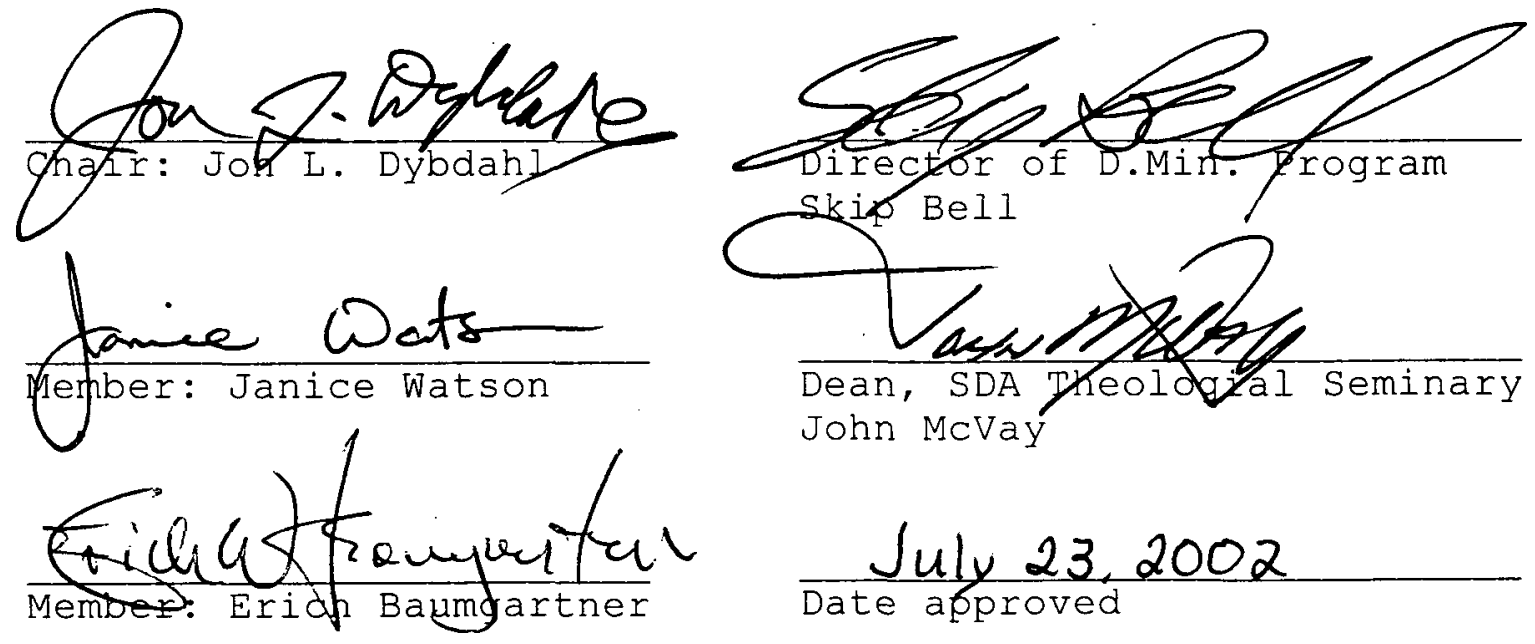


TABLE OF CONTENTS

Chapter

1 .

INTRODUCTION . . . . . . . . . . . . . . . . . . . . 1

Purpose . . . . . . . . . . . . . . . . . . . . . 1

Justification . . . . . . . . . . . . . . . . . . 1

Limitations . . . . . . . . . . . . . . . . . . . 4

Structure and Outline... . . . . . . . . . . 5

2. RELIGIOUS MAGAZINES IN ZIMBABWE . . . . . . . . . 7

Introduction . . . . . . . . . . . . . . . . . . 7

Step Magazine . . . . . . . . . . . . . . . . . . 8

Signs of the Times . . . . . . . . . . . . . . . 9

Afritell . . . . . . . . . . . . . . . . . . . 11

Full Life. . . . . . . . . . . . . . . . . . . . 12

Conclusion . . . . . . . . . . . . . . . . . . . 13

3. THE EDITORIAL DEPARTMENT .............. 14

Introduction . . . . . . . . . . . . . . . . . . 14

The Editor-Publisher . . . . . . . . . . . . . . 14

The Editor's Responsibilities . . . . . . . . . . 15

Target Audience and Need for a

Target Audience. . . . . . . . . . . . . . 16

Choosing the Target Audience . . . . . . . 18

Feature Articles . . . . . . . . . . . . . . . . 22

Developing Feature Articles . . . . . . . 22

Types of Feature Articles . . . . . . . . . . 24

Doctrinal Articles . . . . . . . . . . . 26

Contextualization . . . . . . . . . . . . . . . . 27

Magazine Illustration . . . . . . . . . . . . . 30

Reader Involvement . . . . . . . . . . . . . . . 33

Need for Reader Involvement . . . . . . . . . 33

Attaining Reader Involvement . . . . . . . . 34

Reader's Page . . . . . . . . . . . . . . 36

Local Church Involvement . . . . . . . . . . . . 38

Need for Local Church Involvement . . . . . . 38

Attaining Local Church Involvement. . . . . . 40

Conclusion . . . . . . . . . . . . . . . . . . . 42 
4. DEVELOPING WRITERS . . . . . . . . . . . . . 43

Introduction . . . . . . . . . . . . . . . . . . 43

Identifying Indigenous Writers . . . . . . . . . 45

Experienced Adventist Writers . . . . . . . 45

Experienced Non-Adventist Writers . . . . . 45

Inexperienced Writers . . . . . . . . . . . . 46

Developing the Editor-Writer Relationship . . . . 48

Creating a Healthy Atmosphere . . . . . . . . . . 49

Developmental Training . . . . . . . . . . . . 51

One-Way Training . . . . . . . . . . . . . . . 52

Conferences . . . . . . . . . . . . . . . . . 52

Correspondence Courses . . . . . . . . . . . 53

Internships . . . . . . . . . . . . . . . . . . . 54

Linda Lai's Internship Model . . . . . . . . 54

Internship Program Advantages . . . . . . 56

Writers' Workshops . . . . . . . . . 58

Dual-Training . . . . . . . . . . . . . . 60

Conclusion . . . . . . . . . . . . . . . 60

5. PERSUASION TECHNIQUES . . . . . . . . . . . . . 62

Introduction . . . . . . . . . . . . . . . . . 62

Aristotle's Rhetorical Model . . . . . . . . 62

Ethos of the Communicator. . . . . . . . . 64

Logos of the Message . . . . . . . . . . . . 66

Pathos of the Audience . . . . . . . . . . . . 68

Utilizing the Three Components . . . . . . . . 69

Establishing Common Ground . . . . . . . . . . 70

The "Yes, Yes" Method . . . . . . . . . . . . . 71

A Few Changes at a Time. . . . . . . . . . . 73

Conclusion . . . . . . . . . . . . . . . 74

6. MARKETING . . . . . . . . . . . . . 75

Introduction . . . . . . . . . . . . . . . . 75

Definitions of Marketing . . . . . . . . . 76

Methods of Selling . . . . . . . . . . . . 78

Single-Copy selling . . . . . . . . . . . 78

Transition from Single-Copy to

Subscription selling . . . . . . . . . . 81

Advantages of Subscriptions . . . . . . . . . 82

Increased circulation . . . . . . . . . . . 82

Regular readers . . . . . . . . . . . . 83

Magazine commitment . . . . . . . . . 83

Intra-family reading . . . . . . . . . . . . 83

Acquiring Subscribers . . . . . . . . . . 84 


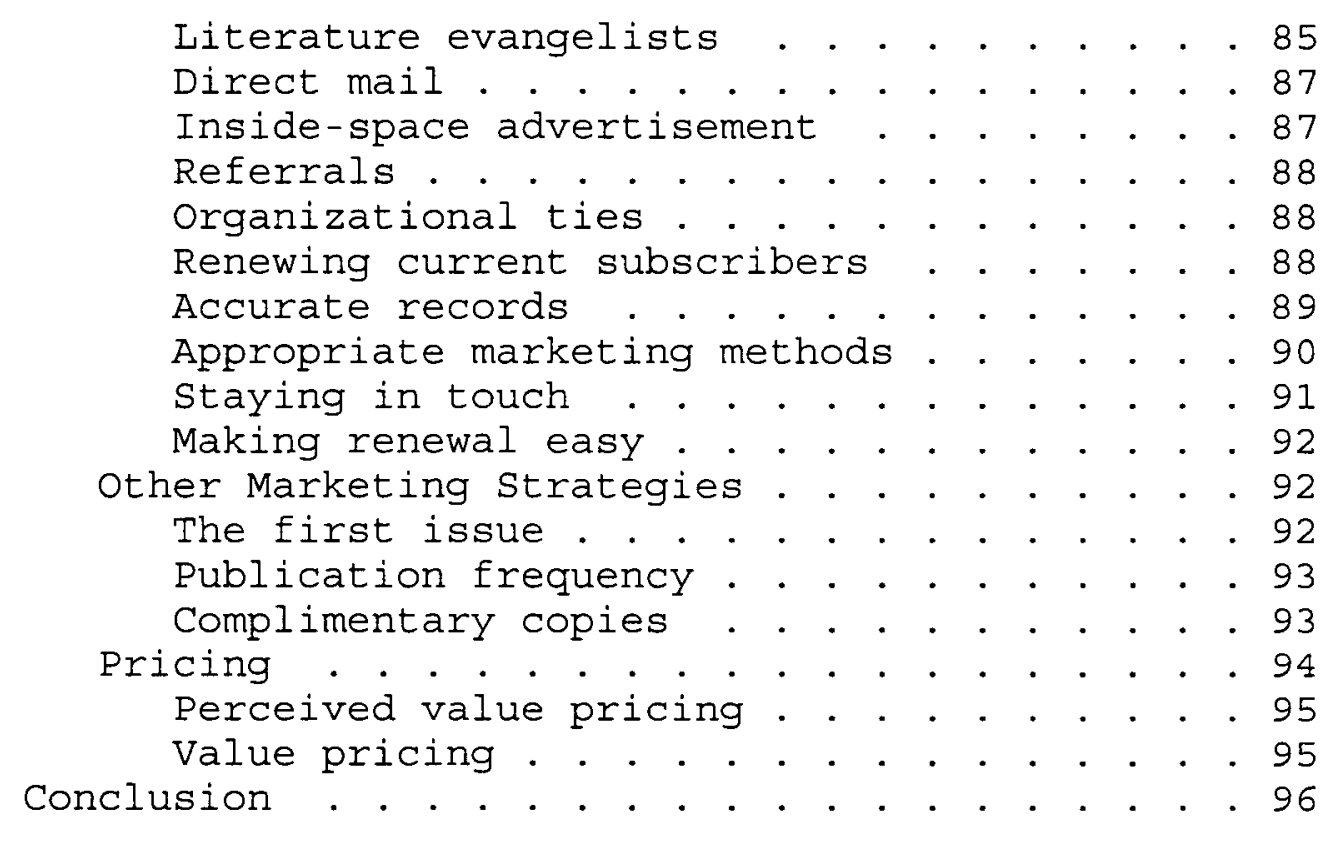

7. FUNDING . . . . . . . . . . . . . . . . . . 97

Introduction . . . . . . . . . . . . . . . . . . 97

State of Zimbabwe's Economy . . . . . . . . . : . 97

Church Leaders' Lack of Confidence . . . . . . . 98

Alternative Sources of Funding . . . . . . 100

Church Members . . . . . . . . . . . 100

Past experiences . . . . . . . . . . 100

Obtaining goal ownership . . . . . . . 101

Benefits to church members . . . . . . . 102

Fund-raising committee . . . . . . . . 103

Talking to potential donors . . . . . . . 104

Start-up funds . . . . . . . . . . . . . 104

Subscriptions for non-members . . . . . . 106

Advertisers . . . . . . . . . . . . 107

Conclusion . . . . . . . . . . . . . 108

8. DEVELOPING SELF-SUFFICIENCY . . . . . . . . . 110

Introduction . . . . . . . . . . . . . . . . . 110

Advantages of Self-Sufficiency . . . . . . . 111

Goals of Self-Sufficiency . . . . . . . . . . . 112

Strategy for Self-Sufficiency . . . . . . . . . 112

Count Costs . . . . . . . . . . . . . . . . 113

Offer Companion Services . . . . . . . . . 113

Manage Finances . . . . . . . . . . . . . . 113

Reduce Costs . . . . . . . . . . . . . . . . 114

Reducing Average Costs . . . . . . . . 114

Hiring the Right Staff . . . . . . . 115 


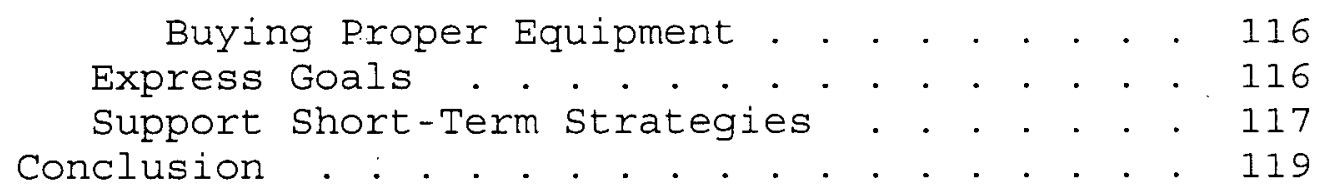

8. SUMMARY AND CONCLUSIONS . . . . . . . . . . . . . . . 120

Summary and Conclusions. . . . . . . . . . 120

Finding the Editor. . . . . . . . . . . 120

Developing Writers. . . . . . . . . . . . . 121

Marketing the Magazine . . . . . . . . . 121

APPENDIX: WRITER TRAINING AND IMPROVEMENT . . . . . . . $\quad . \quad 123$

BIBLIOGRAPHY . . . . . . . . . . . . . . . . . . . . . 140 
CHAPTER 1

INTRODUCTION

\section{Purpose}

The purpose of this dissertation is to design a plan to start a self-supporting evangelistic magazine for the African Seventh-day Adventist church members in Zimbabwe.

\section{Justification}

Throughout history, great movements, religious or political, have relied on the printed page to disseminate their message. Literature has been used to galvanize followers into a force with a sense of mission.

Even before the Seventh-day Adventist church (henceforth abbreviated as SDA church) was formally organized into a denomination in 1863, the scattered believers, numbering about 100, started a paper, The Present Truth, in $1849 .{ }^{1}$ Ellen G. White counseled her husband in

${ }^{1}$ SDA Bible Encyclopedia, vol. 10 (Washington, DC: Review and Herald, 1976), s.v. "Publication Department." 
1848, "You must begin to print a little paper and send it out to the people."1

It was the power of the printed page which established the new believers in the faith and teachings of the evolving SDA church. In short, the paper preceded church organization. The paper acted as a catalyst to church organization. Later, after the organization of the church, numerous papers were published.

The SDA church has operated in Africa for about a century. We have built universities and hospitals and neglected the development of magazines which meet the needs of African people.

A study done by Interlit magazine shows that there is a deep quest for Christian literature in Africa. In Kenya, for example, "a copy of one Christian youth magazine gets read on the average by sixteen people."2

In Zimbabwe, the same tendency can be observed. Christian books and magazines are exchanged many times over. "The more limited the literature is, the more power it

${ }^{1}$ Ellen G. White, Life Sketches (Mountain View, CA: Pacific Press Publishing Assn., 1915), 125. 1991,2 .

${ }^{2}$ Tim Bascom, "Literature with Clout," Interlit, March 
has."1 It appears that now is the most opportune moment to start the proposed magazine in Zimbabwe.

There are currently no Christian magazines in Zimbabwe which are contextualized. David Hesselgrave and Edward Rommen define contextualization as the effort "to present the supra-cultural message of the gospel in culturally relevant terms." 2 This lack of contextualized Christian magazines opens up a good opportunity for the proposed magazine in Zimbabwe. This dissertation involves the concept of contextualization in all aspects of the proposed magazine.

Mario Martinelli's study also shows the critical role played by the printed page in evangelism in the SDA church. He reveals that literature has been responsible for establishing the SDA church in 14.28 percent of the areas where the church is today. ${ }^{3}$

Ellen G. White believed that our publications play a major role in "breaking down the walls of prejudice and

${ }^{1}$ Ibid.

${ }^{2}$ David J. Hesselgrave and Edward Rommen, Contextualization (Grand Rapids, MI: Baker Book House, 1992), 1 .

${ }^{3}$ Mario Paulo Martinelli, "Marketing Strategies for Seventh-day Adventist Literature in Brazil" (D.Min. dissertation, Andrews University, 1996), 2. 
superstition." In another article, Ellen G. White foresaw thousands being converted "most of whom will trace their first convictions to the reading of our publications."2 SDA publications play a critical role in the growth of the SDA church, and any efforts channeled towards the publication of the proposed magazine would enhance our ability to spread the gospel around the world. Unfortunately, financial dilemmas and past experiences with magazine publications in Zimbabwe, as discussed in chapter 7 of this study, have weakened available support for a new magazine. Therefore, it is also necessary that this proposed magazine be designed as self-supporting.

\section{- Iimitations}

Even though there is a great need for enhanced magazine production in Africa, including Zimbabwe, there are many obstacles to the actualization of this endeavor. The very lack of such publications poses many challenges to a study on the feasibility and requirements for establishing a magazine in zimbabwe. Therefore, the study undertaken in this dissertation is not exhaustive. Several areas will need further investigation. A more detailed study on the

${ }^{1}$ Ellen G. White, Counsels to Writers and Editors (Nashville, TN: Southern Publishing Assn., n.d.), 180.

${ }^{2}$ Ibid., 181. 
training needs of African writers is long overdue. Although this study includes a look at the role of the editor, it does not encompass all the aspects of her work.

Also, the chapters which discuss marketing and fundraising strategies mention only those aspects of marketing and fund-raising which apply to this dissertation.

\section{Structure and Outline}

This dissertation is made up of nine chapters. Eollowing the introduction in chapter 1 , chapter 2 briefly surveys the history of religious magazines in Zimbabwe. Special attention is given to magazines published by the SDA church.

Following chapter 2 , the study begins to address the requirements for designing and implementing a successful magazine production in Zimbabwe. Roland Wolseley compares the three major departments in magazine publishing (the editorial, marketing, and funding departments) to a threelegged stool; the publishing business relies on all three departments, and "if any one collapses, the magazine like the stool falls." "These are the departments which the study addresses in chapters 3 through 7 .

${ }^{1}$ Roland Wolseley, "Why Magazines Fail," Interlit, March 1984,8 . 
Chapters 3 and 4 describes the role played by the editor in magazine publishing. The editor's main duties, selecting and editing articles for the magazine, and training indigenous writers are discussed in this chapter.

Chapter 5 focuses more closely on one aspect of writer training and skill: the persuasion of the target audience. Various persuasion theories are presented in this chapter. Chapter 6 deals with marketing strategies for the magazine and outlines the overall, customer-oriented marketing philosophy for the proposed magazine. This chapter discusses, among other things, how to handle single copy sales and subscription sales.

Chapter 7 outlines funding strategies. Fund-raising programs have been suggested to give a strong financial base for the magazine during the inaugural stages of the magazine.

Chapter 8 provides a look at publishing selfsufficiency, including its goals and advantages. Strategies to achieve self-sufficiency are also suggested in this chapter.

Chapter 9 presents a summary of the dissertation and also draws conclusions from the presented information to assist those who will be involved in publishing the proposed magazine. 
CHAPTER 2

\section{RELIGIOUS MAGAZINES IN ZIMBABWE}

\section{Introduction}

A quick search for magazines and newspapers in the bookstores and supermarkets of Zimbabwe would indicate that there is a proliferation of secular magazines and newspapers available in Zimbabwe. Each of these publications is targeted to a particular audience. When it comes to religious magazines, however, the variety is quite limited. Furthermore, the few religious magazines available in Zimbabwe cater only to the needs of a small segment of the religious population. This chapter evaluates the following religious magazines which have been or currently are available in Zimbabwe: Step Magazine, Signs of the Times, AfriTell, and Full Life. This evaluation will show that there is a need for more religious magazines in Zimbabwe. 


\section{Step Magazine}

Step magazine was started in Kenya in 1981 and is reprinted in $\mathrm{Zimbabwe}$ and Ghana through local coordinators. ${ }^{1}$

This magazine's target audience is youth "who may still be only investigating Christianity." ${ }^{2}$ Many young people read step magazine because they find it entertaining. Unfortunately, the articles in the magazine tend to lack spiritual content.

Step magazine uses very graphic cover illustrations. Most of these illustrations depict violence and crime. The colorful illustrations help to make step very popular among the youth.

Step magazine has done a commendable job in training African writers. Almost all of its articles are written by Africans. Step also holds regular writers' workshops to continue the development of its writers.

Step would not be a major competitor to the magazine proposed in this study because of the following reasons: first, step's target audience is high-school teenagers, whereas the proposed magazine's target audience would be post-high-school men and women in white-collar job

\footnotetext{
${ }^{1}$ Lawrence Darmani, "Step Leaps onto Ghana," Interlit, March 1991, 12 .

${ }^{2}$ Horon Wachira, "Can Anyone Be a Writer?" Interlit, September 1993, 15 .
} 
positions; second, Step magazine is not a Zimbabwean-focused magazine. Although many of its articles are relevant to Zimbabwean youth, Step is produced in Kenya and distributed in many African countries. Therefore, step cannot specifically target its zimbabwean readers, as would the proposed magazine.

\section{Signs of the Times}

The South African Signs of the Times (henceforth referred to as Signs) was first published in $1892 .^{1}$ It was intended to serve as a missionary magazine for the SDA Church in southern Africa.

Signs was a monthly magazine from its inception until January 1986, when it became a quarterly magazine. The editor cited rising printing costs as the reason why Signs had to be produced on a quarterly basis. ${ }^{2}$ In December 1989, Signs discontinued publication, ostensibly to give way to a new magazine with a new name and editorial policy. ${ }^{3}$

When Signs resurfaced in 1991, it still bore the same name. However, the editor announced a shift in the

${ }^{1}$ SDA Bible Encyclopedia, 1976 ed., s.v. "South Africa." 1986 .

${ }^{2}$ Eric Webster, "Editorial," Signs of the Times, January

${ }^{3}$ Eric Webster, "Editorial," Signs of the Times, December 1989. 
editorial policy: the Signs magazine would now strive to have "a wider appeal for all South Africans, whatever [their] religion, cultural and social background."1

It is interesting to note that when Signs reappeared in 1991, it was no longer the official missionary magazine for the SDA church in South Africa. The magazine, which is still in business, is now published bimonthly as a selfsupporting project by Eric Webster. Signs currently has a circulation of 15,000 copies. According to Eric Webster, African readers number only a "few hundred" in the entire southern African subcontinent. ${ }^{2}$

It is difficult to determine exactly when Signs began to circulate in Zimbabwe. During the 1960s and 70s, the magazine circulated among SDA white church members in Zimbabwe. In the 1970s, the publishing department in the Zambezi Union mission (now known as Zimbabwe Union Conference) attempted to market Signs to Africans. The project was unsuccessful, mainly because the magazine seemed to have been written mainly for white readers. There were very few articles which were relevant to the needs of African readers. 1991 .

${ }^{1}$ Eric Webster, "Editorial," Signs of the Times, January

${ }^{2}$ Eric Webster, telephone interview by author, 19 October, 1998 . 
In 1980, Zimbabwe became an independent country. The White people began to disappear from the country, and Signs also began to disappear from Zimbabwe. At present, the magazine is almost extinct in Zimbabwe.

The African church leaders in Zimbabwe are quite aware that Signs does not meet the needs of the African readers. Perhaps the most useful solution to this problem would be to let signs focus on its target audience and launch a new magazine which focuses specifically on the needs of African readers.

\section{Afritell}

In 1984, Afritell magazine was launched in Harare to serve the needs of the entire continent of Africa. Afritell was designed to correct the inadequacies of the South African Signs in meeting the needs of the African readers. Afritell was to focus on the needs of Africans. Although the editor, Gerhard Padderatz, was White, he tried to produce a magazine which was truly African. Almost all of the magazine's pictures were of attractive African people. Africans were represented in normal, everyday situations.

Afritell magazine was very popular in bookstores, supermarkets, and newsstands. Unfortunately, the foreign editor left, and the headquarters of Afritell were 
subsequently transferred from Harare to the Ivory Coast in West Africa. As a result of this move, Afritell disappeared from Zimbabwe completely. However, its brief and successful history revealed that there is a need for a magazine like AfriTell in Zimbabwe.

\section{Full Iife}

In 1991, I started Full Life magazine with the support of the East Zimbabwe conference president and treasurer. This was a 32-page magazine intended for outreach purposes.

Our staff did not have a target audience in mind. The magazine was published "for everybody." We also did not have a marketing strategy. The only magazines we sold were through the Adventist Book Center in Harare and Bulawayo. We did not handle any subscriptions, nor did we use illustrations on the cover or inside the magazine.

In spite of these shortcomings, Full Life was relatively successful. We printed only 1,000 copies of the first issue. They sold out in a short time. In the second issue, we printed 3,000 copies. We began to receive unsolicited letters from readers who appreciated the magazine. The third issue was about 5,000 copies, and we managed to sell most of them. Unfortunately, the magazine was not able to continue when I left Zimbabwe in order to study in the United States. 


\section{Conclusion}

The responses of readers to Step Magazine, AfriTell, and Full Life magazine show that Zimbabwean readers appreciate religious magazines which focus on the Zimbabwean people. The difficult history of the South African Signs indicates that African people are attracted to magazines which are sensitive to their needs. The next chapters in this study examine the steps which should be followed in order to produce a Zimbabwean religious magazine that would successfully meet the needs of the Zimbabwean people. 
CHAPTER 3

THE EDITORIAL DEPARTMENT

\section{Introduction}

The introduction to this study outlined the three. important departments of a magazine: marketing, funding, and editorial. This chapter focuses on the editorial department.

\section{The Editor-Publisher}

In the envisaged project, the role of the editor and the publisher will be combined for a couple of reasons. First, the SDA church leaders in Zimbabwe are unlikely to finance the proposed magazine. This conclusion is based on the interviews with SDA church leaders in the Eastern Africa Division (EAD) which are discussed at the beginning of chapter 7. The proposed magazine would therefore need to be self-supporting, which would require the editor to also function as the publisher. Second, if the editor is also the publisher, she will enjoy editorial freedom. A separate publisher might oppose the editor's plans and goals for the magazine, which could hinder or weaken the editor's ability 
to communicate effectively with the magazine's intended audience.

Furthermore, one way to assist the proposed magazine's finances during the early stages of production would be to find a church pastor on the payroll of the conference who would be willing to edit and publish the magazine on a volunteer basis. This would mean that the magazine would not need to pay the editor's salary during the tenuous start-up stages of the magazine. In fact, with sufficient moral support from the church leaders in Zimbabwe towards this project, it might be possible to have the volunteer pastor's conference workload reduced to allow him/her to devote more time to the magazine.

\section{The Editor's Responsibilities}

The success of a magazine, to a large extent, depends on the editor. Susan Miller says, "The editor is the focal point for various tasks involved in producing a publication. - . The look and feel of the final product is linked to the editor's involvement."

This study will consider the responsibilities which the editor must undertake in order to make a magazine successful. From the editorial perspective, a magazine's

${ }^{1}$ Susan Miller, "How Many Readers Do You Have?" Interlit Imprint, unit 1, 1994, 2 . 
success depends on the following: the editor's effort to select a target audience, his/her competence to select the type of feature articles which meet the felt needs of the reader, his/her ability to contextualize the articles, his/her capability to illustrate the magazine, and his/her skill in involving the reader and the local churches in the magazine production. The following sections of this chapter discuss these responsibilities.

\section{Target Audience and Need for a Target Audience}

One of the editor's most challenging responsibilities is to choose a target audience. Choosing a magazine's target audience is a process of dividing readers into potential reader groups, according to various reader tastes. and preferences, and then selecting one group to address through that magazine. The success of the magazine largely depends on the editor's effort in the selection of his/her audience and addressing their needs. Kevin Miller affirms:

Each magazine can reach only one group well. . . In trying to reach everyone most magazines reach no one . . A small circulation made up entirely of logical readers is more valuable than a large one with sprawling circulation in a heavily competitive field. This point is proved by the loss of many large circulation publications in the last 30 years in Western nations. ${ }^{1}$

\footnotetext{
${ }^{1}$ Kevin Miller, "To Market a Magazine," Interlit
} Imprint, unit 12, 1995, 3-4. 
In Zimbabwe, many magazines have a clearly defined audience. Farmer's Weekly, launched in the 1960s, publishes news and articles of interest mainly to farmers. The Financial Gazette is a leading business paper which is read by 91 percent of the business community in zimbabwe and which is also widely read by university graduates who follow economic trends in Zimbabwe. Because the paper has a definite audience whose needs it tries to meet, it has survived for decades when other papers failed. ${ }^{1}$ The Science and Technology Review, a monthly paper also published in Zimbabwe, "attracts professionals, as well as ordinary readers with an interest in science." 2 step magazine, cited in the previous chapter, is a religious magazine for teenagers. It has been in circulation since the beginning of the 1980s.

The conclusion to be drawn from these examples is that in the publishing business in Zimbabwe and elsewhere, the general trend is towards a specialized audience. Magazine editors must choose a target audience because there are too many kinds of potential readers with various kinds of tastes. Some have only basic literacy and have very little

\footnotetext{
"Comment," Financial Gazette, 26 February 1998, 20. "A New Magazine Is Launched," Financial Gazette, 14 May 1998,1 .
} 
reason to read. Some are high-school graduates with a limited grasp of English. Some have a college education with a much deeper understanding of the English language.

\section{Choosing the Target Audience}

The following steps could be taken to choose the target audience for the proposed magazine. First, a demographic segmentation would be undertaken. This is a process of dividing potential readers "on the basis of demographic variables such as age, gender, family size, income, occupation, education, religion and race."1 Much of this information can be obtained from the Zimbabwe Census Bureau. The goal of this demographic segmentation is to select a group which is as homogeneous as possible.

Two factors will be critical in deciding which group to target: reading habits and income level. The age group with the greatest interest in reading and the greatest disposable income will be targeted. If one targets a group which has little interest in reading, the magazine will not sell. If the group enjoys reading but has no disposable income, they will not be able to subscribe.

The target audience of this proposed magazine will be nominal Christian post-high-school men and women holding 
white-collar jobs. This group's reading habits are fairly good by Zimbabwean standards. Blue-collar workers in Zimbabwe generally have poor reading habits because of low education.

The editor should be personally involved in interviewing prospective readers. This would help him or her to understand them well. About 100 individuals from the target group could be selected. Two methods of interviewing could be used: personal and telephone interviews. Personal interviews would be done by visiting selected homes of the targeted audience, and telephone interviews would involve calling households with telephones.

The editor could ask this group of prospective readers about their reading preferences. Do they read religious magazines? If they do, which ones? Do they subscribe to magazines or buy single copies? What type of articles do they appreciate? Would they still buy the magazine if each copy cost a dollar or two more? The answers to the above questions would give the editor a general idea about the prospective readers' interests. The last question would also guide the editor in pricing the magazine.

A demographic segmentation would also help the publisher to determine the magazine's realistic potential circulation. In the West, it has not been possible for most 
religious magazines to capture more than 10 percent of the potential market. ${ }^{1}$

In Zimbabwe the target audience may have less disposable income than a similar audience in Western countries, but other factors outweigh that disadvantage. There is less competition from other magazines in Zimbabwe than in countries in the west. There is also less competition from TV and other forms of entertainment which are so readily available in Western countries. Ironically, the economic disadvantage of the potential readers in Zimbabwe has actually left most people less materialistic than their western counterparts. Indeed, many are looking to God for answers to their perplexing economic and social problems. This makes it easier for a magazine in Zimbabwe to be able to capture a little more of its market than for a magazine in Western countries to do the same.

The survey which the editor could take with prospective readers would give him a general profile of the audience. However, the editor needs more than just a general picture of the readers in order to address their needs meaningfully. He needs to be intimately aware of their needs if he is going to articulate them fluently. This intimate knowledge of the readers' needs would enable him to design a helpful,

$$
{ }^{1} \text { Kevin Miller, } 4 .
$$


useful, and therefore popular magazine. In essence, the editor would be acting from a marketing perspective.

When Breakthrough magazine was launched to meet the needs of teenagers in the 14-17-year age group in Hong Kong, the publisher appointed a group to discover the topics Erequently discussed by high school students during breaks. Because the publisher became closely acquainted this group, and could articulate their needs, Breakthrough magazine enjoyed wide readership. ${ }^{1}$

The editor of the proposed magazine could choose a small group of about six people representative of the target audience and cultivate a close acquaintance with them. She would need to know the physical, social, and spiritual needs of this group. The editor could then ask herself: If the physical, social, and spiritual welfare of this group depended entirely on the articles of the magazine, what sort of articles would be needed? This will be discussed in the section below.

${ }^{2}$ Viggo Soggaard, Media in Church and Mission: Communicating the Gospel (Pasadena, CA: William Carey Library, 1993), 103. 


\section{Feature Articles}

\section{Developing Feature Articles}

The feature articles are those which are given prominence in the magazine. The appeal of the magazine to its reader depends largely on the type of feature articles it carries and how well they are written. The feature articles should not be selected arbitrarily but rather because of their relevance to the readers' felt needs. Zannes defines felt needs as "requirements of life, things we feel we lack."1

Psychologist Abraham Maslow devised a "hierarchy of human needs" which outlined five levels of need:

(1) physiological needs, (2) safety, (3) acceptance, (4) esteem, and (5) self-fulfillment. According to Maslow, these needs motivate humans to search for satisfaction. The most basic needs, such as physiological needs of hunger and thirst, must be satisfied before humans can seek to fulfill "higherorder" needs, such as esteem and self-fulfillment. ${ }^{2}$

The proposed magazine would need to initially discover the level of felt need of its audience. The target audience in Zimbabwe, as post-high school people holding white-collar

${ }^{1}$ Estelle Zannes, Communication: The widening Circle (Reading, MA: Addison, Wesley Pub. Co., 1982), 21.

${ }^{2}$ Ibid. , 22 . 
jobs, would likely be searching to fulfill higher-order

needs related to professional, family, and personal

improvement. In this case, the magazine's articles could

deal with self-improvement and human relationships. By

addressing the appropriate level of needs, the audience

would feel that the magazine is relevant to their lives.

Obviously, this relevance would not only benefit the readers

but would also enhance the marketing ability of the

magazine, simultaneously increasing the chances of reaching

greater numbers of people with the message.

George Y. Hunter III says,

Secular people continue in their assumption that

Christianity is not relevant to their lives until we correlate the facet of the gospel that is good news for their felt needs. The "point of contact" between

Christianity and people is the point at which some facet of the gospel engages a pressing human need. ${ }^{1}$

Bryan Green sets down the following universally felt

needs as providing the points of contact:

A general sense of neediness, loneliness, a fear, lack of purpose, shame, powerlessness to overcome a habit, inability to meet life's demands, a sense of frustration, desire for immortality, . . suffering, moral failure, weakness of will, frustration over evil in the world.'

Rick Warren also argues that the gospel truth must be related to the felt needs of the people. He says that it is

${ }^{1}$ George Y. Hunter III, How to Reach Secular People (Nashville: Abingdon Press, 1992), 100.

${ }^{2}$ Ibid. 
a mistake to think people will flock to the church just because "we have the truth":

While most unbelievers aren't looking for truth, they are looking for relief. I have found that when I teach a truth that relieves their pain or solves their problems, unbelievers say, "Thanks. What else is true in that book?" Sharing biblical principles that meet a need creates a hunger for truth. ${ }^{1}$

\section{Types of Feature Articles}

"How to" articles

Some examples of feature articles which address a few of the universal human needs are "How to Deal with Failure," "How to Discover Meaning in Life," "How to Gain the Power to Live the Life You want to Live," and "How to Cope With Loneliness." These are all examples of "how to" articles. Max Gunther says, "The how to article is one of the most popular types of articles published in today's magazines."2

This was true in the 1960 s when Gunther wrote his book. Today, the Reader's Digest, read by millions around the world, publishes many "how to" articles. There are numerous books in any bookshop with "how to" titles. This suggests the current popularity of this approach. No study has been made to establish how the Zimbabwean African readers respond

${ }^{1}$ Rick Warren, The Purpose-Driven Church (Grand Rapids, MI: Zondervan Publishing House, 1995), 226-227.

${ }^{2}$ Max Gunther, Writing the Modern Magazine Article (Boston: The Writer Inc., Publishers, 1968), 22. 
to "how to" articles, but I suspect their response will not be much different from the responses around the world, since "how to" articles seem to address universal needs.

Rick Warren also highlights the effectiveness of the "how to" approach in communicating the gospel. He believes that "sermons that exhort people to change without sharing the practical steps of how to do it end up just producing more guilt and frustration. People need fewer ought to sermons and more how to sermons." ${ }^{1}$ Although warren is referring to oral communication, this is also true of written communication.

From a marketing viewpoint, Helen Barnhart suggests that the "how to approach should be used as much as possible because 'How to' is one of the most salable word signals in print today."2 Gunther agrees that the "how to" article "seems to attract a certain kind of reader, and this reader remains loyal even when the rest of the magazine is falling apart and other readers are deserting in droves." 3

${ }^{1}$ Warren, 229.

${ }^{2}$ Helen S. Barnhart, "Writing the How To Article," in Handbook of Magazine Article Writing, ed. Jean Fredette (Cincinnati: Writer's Digest Books, 1990), 184.

${ }^{3}$ Gunther, 100-101. 


\section{Doctrinal Articles}

Doctrinal articles should also be related to people's felt needs. Articles on SDA doctrine are very important in an Adventist magazine because they spell out our propositions of faith.

Unfortunately, the majority of Christians do not agree with some of our doctrines, such as sabbath observance. The unchurched may also find doctrinal articles uninteresting or even offensive, so the challenge to the editor is to relate the doctrinal articles to universally felt needs.

John and Millie Youngberg are working on a series of family and biblical sermons to be used in family evangelism campaigns which will attempt to relate the 27 Fundamental Doctrines taught by the SDA church to family life. "A Family Evangelistic Campaign presents the Bible doctrines that would be covered in a traditional evangelistic campaign, making family issues an introduction to and setting for each doctrine." ${ }^{1}$ This approach relates doctrines to felt needs.

Below are a few examples of doctrines which the Youngbergs related to family needs. The Ten Commandments are dealt with under the title "Ten Rules for a Happy

${ }^{1} \mathrm{John}$ Youngberg and Millie Youngberg, Family Life at Its Best, unpublished manuscript, introduction. 
Home."1 The Sabbath is dealt with under the title "The Family Day." 2 The nature of man is discussed under the title "How to Understand Your Spouse." ${ }^{3}$ This imaginative approach turns what could be dry doctrine into an intriguing subject, providing a good example of how the proposed magazine should approach doctrinal articles.

Donald K. Smith concludes that, while it is essential to know the audience's needs, "meeting only their felt needs often ignores deeper spiritual needs. Beginning with felt needs, growing involvement develops communication that touches the spiritual core."4

\section{Contextualization}

As the editor attempts to address the felt needs of his audience through the design of feature articles, much effort should also go towards trying to understand the cultural environment in which the African lives. It is only by understanding the culture of the target audience that the editor can tailor the feature articles to meet the

\footnotetext{
${ }^{1}$ Ibid., 136.

İid., 159 .

${ }^{3}$ Ibid. , 197.
}

${ }^{4}$ Donald K. Smith, Creating Understanding (Grand Rapids, MI: Zondervan Publishing House, 1992), 122. 
audience's needs. "Cultural appropriateness is a major factor in media effectiveness."1

When the audience receives new information, they understand it in relation to their previous experience and their existing beliefs and practices. "An effective communicator knows what the audience has previously known and relates the new to the old is such a way that the audience can give intended meaning to the new message."2

By recognizing that the audience's previous experiences, cultural beliefs, and practices form the building blocks for communication, writers will be eager to work within the culture of their audience. The writers will use metaphors and adages from the audience's background in order to increase the clarity of their message.

Smith points out that "each culture has unique opportunities for the presentation of the message of christ. Effective communication seeks out these opportunities, building the form of the message from within the culture." 3 Smith also argues,

Within every culture will be found keys to the culture, or as they have also been termed, redemptive analogies, bridges to understanding. These existing keys within a

\footnotetext{
${ }^{1}$ Ibid., 207

${ }^{2}$ Ibid. , 265 .

${ }^{3}$ Ibid., 249 .
} 
culture are often witnesses that God has left to himself, and they make possible teaching the fullness of his salvation in Christ. ${ }^{1}$

The earliest Christian missionaries who worked with African people in Zimbabwe left a good example of transforming a given culture by working within it. For example, when the missionaries wanted to teach the biblical concept of God, they first looked at the names of the traditional deity, Mwari, and sought out areas where the traditional Zimbabwean concept of god agreed with the biblical concept of God. The areas of agreement were used as the entrance wedge. The missionaries then put Christian meaning into the non-Christian concept of Mwari (god). By working within the culture to explain non-traditional, Christian concepts, the missionaries allowed the people to gradually accept and understand God through their traditional beliefs.

This approach is known in missiology as "contextualization." Contextualization was previously defined in chapter 1 as the effort "to present the supracultural message of the gospel in culturaliy relevant terms." 2

\footnotetext{
${ }^{1}$ Ibid.

${ }^{2}$ Hesselgrave and Rommen, 1 .
} 
Contextualization is not a new or revolutionary approach to mission. The scriptures provide a biblical basis for it. In his letter to the Corinthians, the apostle Paul described his flexible approach in missions when dealing with people of different cultural backgrounds. He said,

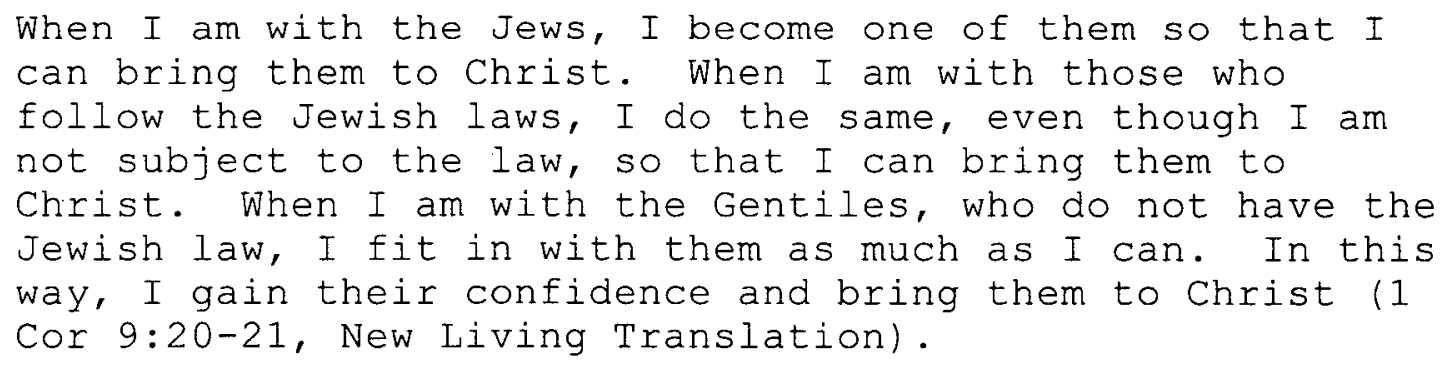

It is important to point out that Paul was committed to being flexible in his methods to reach various cultural groups. He was willing to compromise on social customs but not on the principles of the gospel. If this philosophy is used as a guiding principle, then the new magazine will be more likely to be accepted by the reader, increasing the magazine's marketability and the chances of reaching more people with the gospel message.

\section{Magazine Illustration}

One of the biggest challenges faced by publishers is the magazine or book design. As a result, many of them rely on the old adage, "You can't judge a book [magazine] by its cover": 
They typeset the title, have the printer choose a couple of colors, toss in a photo or illustration and a cover is born. The harsh reality of publishing is that a book [magazine] cover can make or break your profit margin. ${ }^{1}$ Steven scholl believes that it is often possible to predict a book's or a magazine's success or failure on the market by its design. ${ }^{2}$

A magazine that hopes to grab the attention of African readers should give careful attention to its illustrations. According to Morta Bennett, "Africans are very psychologically and physically intuitive. Symbols are important. One needs to sense it to know it." ${ }^{3}$

Benneth exemplifies what he stated above by citing the fabric designs of the Akan people of Ghana which are blockprinted using different kinds of significant symbols. Bennett Says,

"Often a particular symbol would be a reminder of a proverb and thus of certain values." ${ }^{4}$

${ }^{1}$ Steven Scholl, "Design: Its Importance in Marketing," Interlit, June 1995, 19.

${ }^{2}$ Ibid.

${ }^{3}$ Martin Bennett, "Images and Meanings of the Cross in African Christianity," Perspectives, December 1998, 53.

${ }^{4}$ Ibid. 57. 
Many other African tribes including Shona people of Zimbabwe have similar designs on their traditional fabric and their huts. In fact, some of the important symbols. Often the editor is more concerned about the content of the publication than the design. Rhonda Oasterhoff suggests that "if the publication depends heavily on newsstand sales in a competitive market, design concerns should carry mich more weight than if the publication is an organizational information sheet sent free of charge."1

The headlines of a Christian magazine and the cover illustrations must be striking because people are not naturally drawn towards Christian topics. Scholl suggests that a good design should take into account its competitors. ${ }^{2}$ If the design is inferior to that of its competitors, it is likely to fail to capture the market.

Designing is a time-consuming exercise, and many editors do not have the time and skill to design their magazines. As a result, they employ a designer. The proposed magazine enterprise would not be able to afford hiring a designer. It would be cheaper to get the job done

${ }^{1}$ Rhonda Oasterhoff, "Designer Knots," Interlit Imprint, Unit $1,1994,30$.

${ }^{2}$ Scholl, 19 . 
on a contract basis. Even this option would be quite costly, but scholl asserts:

I have found that for many small publishers the cost of contracting a book designer is usually a money saving move. Experienced designers know how to match creative vision and marketing concerns to the practical realities of printing. ${ }^{1}$

Even if a designer is contracted for the proposed magazine, the editor should also be involved in choosing the design; otherwise, the designer may come up with an illustration which offends the readers. The designer should know who the readers of the magazine are. He should also know the principles and practices of the SDA church so that the designs may not be out of harmony with our beliefs and practices.

In summary, although contracting a designer will be expensive, in the final analysis, it will save money by avoiding production mistakes. It will also free the editor to concentrate on editing the magazine. ${ }^{2}$

\section{Reader Involvement}

\section{Need for Reader Involvement}

Besides working with the designer to produce a wellillustrated magazine, the editor may also need to frequently

\footnotetext{
${ }^{I}$ Ibid.

${ }^{2}$ Ibid.
} 
work with the readers to get their feedback. The ultimate goal of the editor as she works with the readers should be to bring them into the magazine publishing business. As they participate in various ways with the production of the magazine, they will develop a sense of ownership. This will be critical in producing a successful, marketable magazine. Communication has been defined as co-response. Smith states that "to communicate with you is to respond to you and to recognize your response to me."1 This definition recognizes that communication is a two-way process. It involves the transmission of messages and the receiving and processing of responses. Without meaningful feedback from the reader, the editor will have merely transmitted a message.

Donald K. Smith argues that "the thread common to almost all ineffective preachers is failure to be involved with the audience." 2 The editor of a magazine will also fail to address the needs of his audience unless the two parties become involved with each other.

$$
\begin{aligned}
& { }^{1} \text { Smith, } \\
& { }^{2} \text { Ibid., } 27 .
\end{aligned}
$$




\section{Attaining Reader Involvement}

How does the editor get involved with the readers?

Below are some suggested ways to reach that goal.

Regular meetings with readers

One way to increase reader involvement is to plan to meet with readers on a regular basis once or twice a. month. The editor could meet with two or three readers and have a working lunch with them during which they discuss the magazine. The editor could find out what the readers think about the magazine. What aspects of the magazine do the readers like? What needs improvement? Which articles do the readers find most meaningful to them and why?

Mwaura Njoroge, the editor of Today in Africa, believes that the feedback from the readers "can help the editors know whether they are meeting the needs of their audience, and it allows the reader to participate in the making of the message."1

'Mwaura Njoroge, "Involve Your Reader," Interiit, June 1989,12 . 


\section{Reader's Page}

Another method of involving the readers is by reserving two or three pages for them in the magazine. One page could be for letters from the readers. On this page, the readers could share their views on any subject covered by the magazine. The editor could use this column to gauge the reaction of the readers to the articles in the magazine. Donald Smith, in his discussion on media effect, says that "the value of a programme is measured by letters of response." 1

Another page could be reserved for readers' favorite quotations. The readers can share a favorite adage or quotation. The name of the sender should be printed after the quotation. One line or two could say who the sender is. Most people love to see their names in print, so this practice will make people who communicate with the magazine feel honored and appreciated. Readers are more likely to develop stronger loyalty to a magazine which shows interest in its readers.

Today in Africa magazine involves its readers in a practical and productive way. In each issue of Today in Africa, a question is printed and readers are invited to answer. The best responses are printed in future issues.

\footnotetext{
${ }^{1}$ Smith, 198.
} 
The winning ones get book prizes and two magazines. The questions asked are related to themes for future issues. ${ }^{1}$ Some examples of questions are: "Why do teens drop out of church?" and "What do you think about ancestral worship?" Each question usually addresses a current problem in the church.

The questions usually have four parts:

1. Causes of the problem

2. What Christians can do to help

3. The church's stand concerning the issue

4. Bible teachings and possible solutions. ${ }^{2}$

How does this affect the marketing of the magazine? Today in Africa has discovered that this method not only increases readers' participation but boosts sales as well. ${ }^{3}$ Njoroge says that when his magazine responds to the readers'. questions and needs, "our readers feel compelled to keep reading. By answering questions, we have not only been able to retain old readers but we have acquired new ones." 4

Today in Africa also encourages readers to participate in Bible contests. The Bible contests introduce the readers

\footnotetext{
${ }^{1}$ Ibid.

2Ibid.

${ }^{3}$ Ibid.

"Ibid., 13.
} 
to a book of the Bible. The readers are encouraged to read the book and answer questions. The contests consist of eleven questions, ten of which are tightly structured. They deal with important texts in the Bible. Question 11 requires the reader to write an essay. The essay measures the ability of the reader to apply what they have learned. ${ }^{1}$ The contest selects only ten winners, but they get as many as 120 responses. Today in Africa discovered that the Bible contests not only generate interest among the readers but also boost sales because participants buy the magazine to discover the results of the contests. ${ }^{2}$

In the envisioned magazine, the different methods of involving the reader discussed above would be tried. This would ensure that the magazine would not just be transmitting the message but also communicating with the audience.

\section{Local Church Involvement}

\section{Need for Local Church Involvement}

While it is important for the editor to be in contact with the reader, it is just as important to get the readers

\section{${ }^{1}$ Ibid.}

${ }^{2}$ Ibid. 
involved with the local SDA church members. The reasons are discussed below.

Communication experts have discovered that people communicate through many systems, including (1) verbal, written, (3) audio (use of non-verbal sounds and silence), (4) kinesic (body motions, facial expressions, and posture), (5) tactile (touch), (6) spatial (use of space), and (7) olfactory (taste and smell) systems. ${ }^{1}$ An attempt to communicate the gospel through the printed page utilizes only one of the signal systems of communication. Many of the signal systems at play in a face-to-face interaction are missing. As a result, the printed page alone is often not as effective as Christians should want it to be for gaining decisions for Christ.

Donald Smith argued that public media, such as a Christian magazine, are effective in creating awareness and interest. They can be effective in breaking down prejudice. ${ }^{2}$ "The choice to change usually results from contact with friends who recommend or support the decision."3

Smith also noted that in the United States there is massive evangelical broadcasting "but very little gain in

$$
\begin{aligned}
& { }^{1} \text { Ibid., } 146 . \\
& { }^{2} \text { Ibid., } 326 . \\
& { }^{3} \text { Ibid., } 328 .
\end{aligned}
$$


church membership."1 The major reason is that little attention has been paid to interpersonal networking. This fact suggests that the involvement of the local church members with the readers of the envisioned magazine is not optional but essential.

\section{Attaining Local Church} Involvement

The local churches can be involved with the readers of the magazine through several ways. First, the editor could offer a free subscription to all the SDA pastors in Zimbabwe, about 125 people according to Paminus Machamire, the Zimbabwe Union president. ${ }^{2}$

The editor could also request suggestions from the pastors on how the magazine could be used for evangelistic purposes. By asking for their ideas and then incorporating some of them into the magazine, the editor gives the pastors a sense of ownership and involvement. This is critical to winning their support and increasing their readiness to promote the magazine to their church members.

The editor could also personally visit the churches to promote the magazine. She could give the names and

\footnotetext{
${ }^{1}$ Ibid. , 320

'Paminus Machamire, interview by author, 20 April, 1998.
} 
addresses of people subscribing to the magazine and ask church members to befriend them. The church members would be urged to read the magazine and know its contents as well. This would help them to discover some common ground with the readers of the magazine. In essence, the magazine would be seen as a vital part of the church's friendship outreach with the people of Zimbabwe and would therefore increase church-member support for the magazine. This grass-root support for the magazine would be of utmost necessity for the success of the magazine endeavor.

Donald Smith suggests the creation of readers' clubs to establish closer links between the media and the local churches. Church members who are already reading the magazine could initiate the formation of such clubs. ${ }^{1}$

The readers' club could promote a healthful lifestyle. Club members could also meet regularly at the gymnasium for exercises. They could arrange marriage seminars and meet for potlucks. The church should take great care not to pressure readers to make the decision to accept christ. The role expected of them is to befriend the readers, answer their questions, and invite them to the church. Donald

\footnotetext{
${ }^{1}$ Smith, 194.
} 
Smith says that more than 80 percent of those who accept Jesus as their Lord begin that journey through friends. ${ }^{1}$

\section{Conclusion}

In summary, to communicate more effectively through the proposed magazine, the editor must not only work on editing the magazine, but he must also interact with the readers to gauge their reaction. He must encourage church members to interact with the readers and support their decisions to accept Christ. The editor would assume the dual position of editor and publisher as a result of the self-supporting magazine design and also to allow for more editorial freedom. The editor must also utilize reader involvement and cultural understanding to benefit the marketing aspect of the magazine. These varied approaches are essential for effective magazine communication.

${ }^{1}$ Ibid., 100. 
CHAPTER 4

\section{DEVELOPING WRITERS}

\section{Introduction}

Isaac Phiri, editor of Interlit, claims that one of the biggest challenges facing magazine publishing in Africa is finding well-written articles for the magazines. ${ }^{1}$ George Mbuggus, editor in chief of The People, magazine published in Kenya also says that the biggest challenge he faces as an editor is getting well trained and talented writers. ${ }^{2}$ There are two main reasons for this difficulty. First, indigenous Christian magazines are relatively new in Africa. As a result, the publishers of these magazines have not had sufficient time to discover and develop a dependable pool of local writers. Second, many Christian magazines in Africa do not pay their writers. As a result, there is very little financial incentive for writers to continue writing.

${ }^{1}$ Isaac Phiri, interview by author, 7 July 1996.

${ }^{2}$ George Mbuggus, "Hunting for Talent in Kenya" Media Focus, January 1999, 15. 
Because of this shortage of writers in Africa, editors should have a vested interest in discovering and training indigenous African writers. The writers are responsible for producing magazine articles which will meet the needs of the target audience. As the previous chapter pointed out, the magazine can only be successful if it fulfills the felt needs of the target audience. The editor and the writer form a symbiotic relationship: The success of the editor's work depends on the availability of well-written articles, while the writers need an editor to guide them in their writing career and to direct their articles towards a particular audience. In order for this relationship to prosper, the editor and the writers must be on the same level of ability and understanding, a state which can be achieved by proper writer training. Horon Wachira, the editor of step magazine, believes that "every magazine publisher must see [writer] training as a basic necessity."1

${ }^{1}$ Horon Wachira, "Thoughts on Publishing a Magazine," Interlit, March 1986, 13. 


\section{Identifying Indigenous Writers}

\section{Experienced Adventist Writers}

In the proposed magazine, the first step towards developing writers would be to identify SDA Christians who are already writing for the secular press or other Christian magazines. There are numerous Adventist authors in Zimbabwe currently writing for secular magazines such as Sunday Mail, Financial Gazette, and The Herald, the largest national daily newspaper in Zimbabwe.

These established writers would be requested to write Christian articles for the new magazine. The advantage of tapping from writers who have been writing for the secular press is that many of these writers already have a lot of credibility, which they would bring to the new magazine. Some of them have also built up reader loyalty outside of Adventist circles. Their expanded readership could help to attract readers to the proposed magazine. By utilizing experienced writers with existing readerships, the proposed magazine could greatly benefit from a marketing perspective as well as from a evangelistic perspective.

\section{Experienced Non-Adventist Writers}

Efforts would also be made to identify non-Adventist Christian writers. These writers could be assigned to write devotional and psychological articles which would be 
unlikely to raise theological problems with the Adventist church. If these non-Adventist writers have credibility in their own Christian denominations, the credibility of the magazine would also be enhanced in the eyes of readers previously acquainted with those writers.

\section{Inexperienced Writers}

Of course, the proposed magazine would not be able to rely solely on existing, professional writers. Therefore, careful planning and effort would be invested in recruiting and training non-writers. Miriam Adeney, who is involved in the writer training programs at Regent College, says:

When we invite applicants, we don't ask for writers. They don't even need to like writing. We ask for people who have: a passion to communicate, a mature Christian world view, credible character, teachability and perseverance. ${ }^{1}$

Adeney attests that, with hard work and by following guidelines, any writing trainee can produce manuscripts which can be published. ${ }^{2}$ The experience of Linda Lai, former editor of Interschool Christian Fellowship Monthly, supports Adeney's claims.

Lai wanted to get high-school students involved in writing for her Hong Kong-based magazine. First, she opened

${ }^{1}$ Miriam Adeney, "Writer Training: God Gives the Increase," Interlit, April 1997, 12.

${ }^{2}$ Ibid. 
up a column in her magazine where the students could write about their experiences. After that, she decided to offer writer's training to any interested students. Lai's first writing trainees were two students who had been involved with the Interschool Christian Fellowship magazine. She asked them to invite their friends. Three girls and two boys attended the first training program. ${ }^{1}$

After months of training, most of the editing and writing for the entire magazine was being handled by the students whom Lai had trained. In fact, one of Lai's five students, Fong, went on to become a member of the editorial board for one of the Christian newspapers in Hong Kong. ${ }^{2}$ While education is a major advantage in writing, lack of it should not be viewed as a hindrance. Simon K. Mureu, one of the most published Christian writers in Kenya; went to school only up to the seventh grade. His passion to communicate was so strong, however, that he struggled to write for many years before he finally broke into print. Today, Mureu is one of the most prolific Christian writers in Kenya. ${ }^{3}$

\footnotetext{
${ }^{1}$ Linda Lai, "Writer Training," Interlit, September 1989,18 .

${ }^{2}$ Ibid.

${ }^{3}$ Simon K. Mureu, "Writing Is Not only for the Educated," Interlit, september 1995, 18.
} 
In Zimbabwe, there are thousands of SDA members with university degrees. There are also thousands with high school and college diplomas. This means there is a large group of prospective writers. With encouragement and training, many of these inexperienced writers can become productive and effective article writers. Costa advises that the editor should train more writers than she actually needs, since the publisher can expect to retain about $10-15$ percent of all the prospective writers she trains. Of this 10-15 percent, some prospective writers will continue to improve and become effective writers, but others will not.

\section{Developing the Editor-Writer Relationship}

After identifying any writers who would be interested in writing for the proposed magazine, the next step towards attaining well-written articles for the proposed magazine would be to develop a healthy relationship between the editor and the writers.

${ }^{2}$ Charlie Costa, "Editorial Traits That Build Writers," Interlit Imprint, unit 13, 1996, 6. 


\section{Creating a Healthy Atmosphere}

When dealing with writers, especially novices, editors should be careful to create a nurturing atmosphere for the editor-writer relationship. Charlie Costa advises:

Many times editors are the worst enemies of their eager, but often confused writers. . . . Whether good or bad, the writer-editor relationship ultimately affects the final product. . . Positive, constructive relationships tend to help writers become more cooperative and productive. ${ }^{1}$

In order to build these positive, constructive relationships, the editor should edit with respect. Tim Bascom has set down some guidelines to help increase the editor's respect for the writer's work:

1. Editors should improve the writing and not the opinion. "If the writer has said something poorly, change it. But don't impose your own opinion in place of another."

2. The editor should also distinguish between true writers and experts who are simply trying to communicate what they know on a topic. A writer cares about every word she uses, while a topical expert is often happy for the editor's help in clarifying the communication of the expert's knowledge.

\section{${ }^{1}$ Ibid.}

${ }^{2}$ Tim Bascom, "Thought Crimes," Interlit Imprint, unit $13,1996,4$. 
3. Editors should let the writers see their manuscripts which have undergone major changes before they are published. If the writers are aware of how and why their article has been changed before publication, they will be less upset by the changes.

4. If an article contains inaccurate information or unsupported opinions, the editor should return it for revision, explaining the need for revision in a carefully written letter. This will give the writer a second chance. ${ }^{1}$

Charlie Costa also suggests ways that editors can build up writers. He counsels editors, "Before anything else, look for the positive aspect of a manuscript."2 Because editors spend much of their time trying to improve manuscripts, it is easy for them to focus on what is wrong with a manuscript. However, if the editor looks for the positive qualities first, the writer will then be more open to any following criticisms which the editor might express.

Costa also warns editors to avoid the "red ink syndrome." Costa believes that an editor's corrections written in red ink on top of a writer's work psychologically intimidates the writer. He suggests editing with pencil and

\footnotetext{
${ }^{1}$ Ibid.

${ }^{2}$ Costa, 7
} 
writing corrections in the margin of the article draft as signs of respect for the writer's ability and efforts. Isaac Phiri suggests that editors should answer any correspondence from their writers. Phiri says that writers want to know if their manuscript has been rejected or accepted. He also suggests that editors should not hold onto the manuscript for more than a few weeks without letting the writer know the decision. ${ }^{1}$

\section{Developmental Training}

When writers know that the editor is sensitive to their abilities and efforts, their creativity is challenged, and they will strive to produce more creative and effective articles. However, writers need the tools to continually improve their writing skills in order to meet the goals of . the editor. The editor can provide these tools through developmental training programs for writers.

The following methods of training could be used to develop writers for the envisaged magazine: (1) one-way training, (2) conferences, (3) correspondence courses, (4) internships, and (5) writers' workshops. ${ }^{2}$ Each of these

"Isaac Phiri, "Editors are Good Neighbors," Interlit Imprint, unit 13, 1996, 19.

"Interact for Impact," Interlit Imprint, unit 16, $1996,21$. 
will be discussed respectively. The information which will be used in these training methods is described in detail in Appendix A.

\section{One-Way Training}

This method trains the employee by using books, magazines and other resources about writing. The main advantage of this method is that it is fairly inexpensive. The trainees get the resources and train themselves. ${ }^{1}$

This method has its disadvantages. First, there is no accountability for progress. Second, there is no interaction with others. ${ }^{2}$ The writing trainees must be highly self-motivated to benefit from this method.

\section{Conferences}

In this method, professional writers and editors hold training conferences for prospective writers. The advantage of this method is that it provides much-needed support from colleagues in the field. The fellowship provided also stimulates creativity. The aspiring writers can also receive valuable information from the expert writers. ${ }^{3}$

${ }^{1}$ Ibid.

${ }^{2}$ Ibid.

${ }^{3}$ Ibid. 
The disadvantage of this method is that most conference cannot be held for a sufficient time period to provide individual attention or to focus on solving specific problems. ${ }^{1}$

\section{Correspondence Courses}

Many people advance themselves professionally by taking correspondence courses. The correspondence programs require students to complete assignments which are checked by instructors and returned to them. The instructor's comments are often detailed and very helpful. The advantage of this method is that it is less expensive than formal training in a college. There are several correspondence schools in Zimbabwe which offer courses in journalism and short-story writing .

The disadvantages of correspondence studies are similar to those of one-way programs: education by correspondence requires a lot of self-discipline, perhaps more than most people can maintain, and accountability is also very low in this method. ${ }^{2}$

\footnotetext{
${ }^{1}$ Ibid.

${ }^{2}$ Ibid.
} 


\section{Internships}

The internship method of training is tailored "for one individual with specific, pre-planned goals."1 In the internship program, "the activity strategy is the practice of a particular skill for improved performance on the job."2 The emphasis is "try and try again." ${ }^{3}$

Internship training provides a number of advantages. "The learner is placed alongside an experienced practitioner. Work must be real, not pretend. It also must not only be work for work's sake, but it must have a training dimension to it." 4 Many publishers train writers using the internship training method.

\section{Linda Lai's Internship Model}

Linda Lai's method to recruit and train potential writers for Interschool Christian Fellowship Monthly was mentioned earlier in this chapter. However, the actual steps which Lai used provide a valuable model for the internship method of developing writers' abilities and

${ }^{1}$ Ibid.

2 "The Spectrum of Training," Interlit Imprint, unit 16, $1996,24$.

${ }^{3}$ Ibid.

${ }^{4}$ Larry Brook, "Learn by Doing," Interlit Imprint, unit $16,1996,23$. 
skills, so the study will now focus more closely on Lai's experience.

Lai wanted high-school students to participate meaningfully in Interschool Christian Fellowship Monthly. As editor of the magazine, she opened a column in the magazine for students to share their experiences. She then chose students who had written for this column to include in her training program. ${ }^{1}$ Lai says that in the first two months of training, all she and her five students did was pray, study the Bible, and focus on personal growth. In the fourth month, Lai began to introduce her students to writing skills and interviewing. Beginning in the sixth month, they spent half an hour of each meeting actually writing. What they wrote was published in the special column of Interschool Christian Fellowship Monthly. ${ }^{2}$ Lai assigned the students to edit stories and articles. Lai says, "Gradually, we found ourselves maximizing each other's strengths. Lam [one of Lai's students] had a sound mind and gifts in leadership. He edited more monthly issues and sometimes chaired business meetings."3 Lai concludes, "Today the writing team is already in its second generation

$$
\begin{aligned}
& { }^{1} \text { Lai, } 18 . \\
& { }^{2} \text { Ibid. } \\
& { }^{3} \text { Ibid. }
\end{aligned}
$$


under a new leader, and I no longer work with the Interschool Christian Fellowship Monthly. ${ }^{1}$

\section{Internship Program Advantages}

The internship program offers many powerful advantages to the proposed Zimbabwean magazine. First of all, as Lai points out, the "intense involvement provides lasting expertise in the individual." ${ }^{2}$ The training could also be simultaneously tailored to meet the needs of the individual and of the organization.

Additionally, internship training models similar to Lai's program could be replicated anywhere. The internship training program of the envisaged magazine in Zimbabwe would target unemployed high school graduates with reasonable grades in English literature at the advanced level. Students who have passed English literature at the advanced level will have usually covered important areas such as literary criticism and are also relatively proficient in the use of English. Furthermore, these students would quite likely be highly motivated, as indicated by their grades, and this motivation would be a valuable asset to the magazine.

${ }^{1}$ Ibid.

${ }^{2}$ Ibid. 
In Zimbabwe, a student can obtain two high-school certificates. The first one (Ordinary level certificate) is obtained after the first four years of high school. Those who hold the Ordinary level qualify for university studies in most countries, including the United States. To qualify for a Zimbabwean university, the student must study for two more years to obtain an Advanced level certificate. Because there are not enough Zimbabwean universities to absorb all high-school graduates, many potential students often wait for an interim period of two or three years before they can be admitted to a university in zimbabwe.

Another advantage of the internship training program would be that it would provide a meaningful and useful way for these students to occupy their interim period. They would welcome the training as an opportunity to sharpen their communication skills and also to gain selffulfillment in life. By selecting writing trainees from this group, the training program would not only meet the needs of the magazine but also those of the individual trainees.

Furthermore, Lai's training model would train potential editors as well as potential writers. In Africa, one of the major reasons for the collapse of magazines is that the founding editors do not train anyone to take over their 
position after they leave. When the editors leave, the magazines sometimes collapse.

\section{Writers' Workshops}

Writers' workshops are one of the most dependable methods of training writers. Many prolific writers began their careers at a writer's workshop. However, a lot of planning and creativity is involved in organizing successful writers' workshops. Larry Taylor advises, "The organizer can count on success if he or she does two simple things to get started: first, assemble a group, be it large or small; second, schedule meetings in an established location." I

The first meeting would be especially crucial. It is here that participants would get to know each other. The members would also be given a chance to say something about themselves. The participants could talk about their reading preferences, their previous writing experience, or their work interests and experiences.

The organizer would outline what the workshop is all about and what the participants would be expected to accomplish. The meeting timetable should be set; the group could meet on a weekly or biweekly basis. ${ }^{2}$

${ }^{1}$ Larry Taylor, "Organize a Writers. Workshop," Interlit, March 1995, 15.

${ }^{2}$ Ibid. 
The workshop organizer should also set a friendly and supportive tone. The organizer should let the participants know that each workshop will involve five stages: (1) a devotional, (2) reading parts of a manuscript aloud, (3) reactions to the following questions: "What do you like?" and "What bothers you?"14) receiving positive and negative criticism, listening as carefully to the latter as to the former, and (5) discussing ideas for character, plot and technique in a new project to be worked on over the next few weeks. ${ }^{2}$

The workshop participants would set deadlines for submitting an article or short story, about ten pages in length. For the first assignment, the participants would need four to six weeks to complete it. They could agree on the number of pages each participant must bring to share at the next meeting. These would be story or article ideas, not the finished product.

The organizer would emphasize that writing should be done at home. Workshops would be dedicated to discussing problems, discovering new ideas, and critiquing each other. ${ }^{3}$

\footnotetext{
${ }^{1}$ Ibid.

${ }^{2}$ Ibid.

${ }^{3}$ Ibid.
} 


\section{Dual-Training}

The goal of any and all writer-training programs carried out by the editor of the proposed magazine would be to enable writers to fluently communicate the message of salvation within the African context. To achieve this goal, a dual-training viewpoint would be applied to all training and development methods. One aspect of every training and development program would aim at sharpening writing skills. The second aspect would focus on deepening the Christian experience of each prospective and developing writer. When the latter has been achieved, the writer will write out of personal conviction and with a purpose. Readers can sense the conviction and the urgency which an author attempts to convey in his writing. In fact, the whole quality of the article or story is affected by the author's personal spiritual development.

\section{Conclusion}

In summary, if the editor wants to have a pool of dependable and competent writers for the proposed magazine, he needs to search for indigenous Christian writers. The editor also needs to recruit and train new writers. Several methods of training writers, such as the internship methods and the writers' workshops, could be used to develop indigenous writers. The programs would best benefit the 
magazine if they are designed from a dual-training perspective, which will increase the writing skill and Christian experience of the writers.

The programs to develop writers suggested above have been successful with other publishers who were keen to develop their own pool of writers. If these programs are implemented carefully, the new magazine would be able to train and continually develop writers who could supply the magazine with good articles. The articles which properly trained writers could create for the magazine would target the spiritual and social needs of the audience, and this would simultaneously increase the marketing capability of the magazine and enhance its spirituality and evangelism influence. 
CHAPTER 5

\section{PERSUASION TECHNIQUES}

\section{Introduction}

The previous chapter provided an overview of training models which could be used in training article writers for the proposed magazine. However, one of the main aspects of article-writing, persuasion, requires a detailed discussion of its origins and implications. Therefore, this chapter focuses exclusively on persuasive theory and techniques.

\section{Aristotle's Rhetorical Model}

One of the main goals of the writer-developmentaltraining programs described in the previous chapter is to develop effective writers. The editor provides training for the writers to ensure magazine articles which can grab the readers' attention and cultivate their interest in the magazine's message.

A crucial element of article-writing which the editor and the writers (referred to as "writers" for the rest of this chapter) can use to develop their writing skills is persuasion theories. Charles U. Larson defines persuasion 
as "communication intended to influence choice."1 Estelie Zannes expands Larson's definition to include beliefs as well as behaviors: persuasion tries to get others to "believe and feel as we do and modify their behavior with regard to belief."2

The ancient Greek philosopher Aristotle studied effective communicators of his time and came up with a. rhetorical model which has been effective for twenty-three centuries. 3 "Rhetoric" involves "discovering all the available means of persuasion in a given case," 4 and Aristotle's model provides valuable insights for magazine writers to enhance their written persuasive skills.

Although Aristotle's rhetorical model was primarily concerned with speech and convincing through oral communication, medieval and Renaissance scholars applied it to writing styles. ${ }^{5}$ Today, writing and speech teachers both use this model to enable their students with enhanced

\footnotetext{
${ }^{1}$ Charles U. Larson, Persuasion Reception and Receptability (Boston: Wordsworth Publishing Company, 1995), 9 .

${ }^{2}$ Zannes, 124 .

${ }^{3}$ Hunter, 74 .

${ }^{4}$ Zannes, 124 .

${ }^{5}$ Erica Lindemann, A Rhetoric for Writing Teachers (Oxford: Oxford University Press, 1995), 46.
} 
persuasive abilities. According to Barry Ulanov, "The rediscovery of classical rhetoric has more potential for improving the way young people write than any other current movement in education."1 Because of its effectiveness in developing writing skills, Aristotle's rhetorical model will be used to explain and improve persuasive ability of the articles for the proposed magazine.

According to Aristotle, effective communication has three components: the communicator, the message, and the audience. Aristotle taught that persuasion is a result of interplay between the ethos of the communicator, the logos of the message, and the pathos of the audience. ${ }^{2}$ The following sections of this chapter discuss these three components of persuasion respectively to show how the writers (the communicators) can more effectively convey the fulfillment of felt needs (the message) to the readers of the proposed magazine in Zimbabwe (the audience).

\section{Ethos of the Communicator}

Aristotle used the ethos of the communicator to refer to the communicator's characteristics of intelligence,

'Barry Ulanov, "The Relevance of Rhetoric," in Rhetoric and Composition, ed. Richard L. Graves (Rochelle Park, NJ: Hayden Book Company, 1984), 293.

${ }^{2}$ Hunter, 74 . 
character, and credibility which are perceived by the audience. If the audience believes the communicator to be well-informed, moral, and interested in the welfare of the people, the audience tends to be persuaded by her message. ${ }^{1}$ The audience's receptiveness to credible writers carries several implications for the writers. The writers should read widely in order to raise their knowledge and intelligence levels, which will show through their writing. The writers should also write on subjects with which they are familiar. Research for the articles should be done by reading or by conducting interviews. "When it is clear that speakers have not researched their topic, they diminish their ability to persuade."2 The same can be said for writers, for an article's ability to persuade its audience depends on proper research by its writer.

What the audience knows about the communicator may influence her ability to persuade the audience. The audience often wonders if the communicator has the background to write on a given subject. ${ }^{3}$ If the writer does not have the background to write on a particular subject,

${ }^{1}$ Ibid.

'J'ohn Makay, Public speaking (Philadelphia: Harcourt, Brace \& Jovanovich College Pub., 1992), 338.

${ }^{3}$ Ibid. 
she could interview an authority on that subject. For example, if the article's subject is crime, the writer could interview the Harare Chief of Police. For an AIDS article, the writer could interview the head of the AIDS Control Trust in zimbabwe. The writers should not give the readers the impression that they are just writing about their personal opinions on a topic.

The editor could also enhance the writers' credibility by including their academic achievements, experience, and honors at the end of the article.' In short, any favorable information about the writer makes the readers more likely to accept the writer's, the article's, and the magazine's point of view.

\section{Logos of the Message}

John Hasling defines Aristotle's term logos as "the facts, the evidence, and the reasoning" in a given piece of writing. ${ }^{2}$ Communicators who focus on evidence hope to persuade their audience that their position is backed by reason. Makay believes that when communicators "present strong arguments, backed by solid evidence and logical,

${ }^{1}$ Wayne C. Minnick, The Art of Persuasion (Boston: Houghton Mifflin Co., 1968), 162-163.

'John Hasling, The Audience, the Message, the Speaker (New York: MCGraw-Hill Book Co., 1976), 78. 
clear reasoning, they increase the likelihood that the audience will respond favorably to their message."1

Sound reasoning is especially important when dealing with a skeptical audience. Writers should avoid drawing conclusions in an article without first presenting sufficient supporting facts for the conclusion. They should also avoid selecting only evidence or facts which support their case. The audience is likely to reject the communicator's position if the audience feels that facts and information are being withheld.

The writers should anticipate the audience's doubts and questions and address them effectively. One effective way to counteract opposition to an article's topic would be to list opposing arguments and then systematically provide evidence against those arguments. ${ }^{2}$

Another way to enhance the logos of articles on religious topics would be to quote scripture or authorities such as John Wesley or Billy Graham who support the position of the article. The writer could also use supporting quotes by celebrities or people who are greatly admired by the audience for their good character. People "are strongly

$$
\begin{aligned}
& { }^{1} \text { Makay, } 341 . \\
& { }^{2} \text { Ibid., } 356 .
\end{aligned}
$$


inclined to accept as true statements made by persons whom they admire and respect."1

\section{Pathos of the Audience}

Aristotle used pathos to refer to the emotional state of the audience. ${ }^{2}$ Aristotle discovered that people respond differently to information when they are in different emotional states, such as when they are angry versus when they are amused.

Aristotle taught his students how to influence the emotional state of their audience in order to increase the audience's acceptance of the message. ${ }^{3}$ "Emotional appeals are often the most persuasive types of appeal because they provide the motivation listeners need to change their minds or take action." ${ }^{4}$ For example, instead of simply listing the reasons why smoking is unhealthy, a more effective method of convincing an audience to stop smoking is to show them the frightening agonies of someone dying of lung cancer. "Often the only way to get an audience to act is to combine persuasive evidence with a strong ëmotional

\footnotetext{
${ }^{1} \mathrm{Minnick}, 161$.

${ }^{2}$ Hunter, 75 .

${ }^{3}$ Ibid.

${ }^{4}$ Makay, 354.
} 
appeal."1 By using specific details, anecdotes, and emotional language, the writers can engage the audience's emotions and increase the article's chances of affecting people's lives.

However, emotional appeals must not be abused in order to manipulate or control others. Aristotle taught that the communicator's first duty is to present ideas through sound evidence and reasoning and not through excessive emotional appeals. Emotional appeals should be based on strong reasons and evidence. ${ }^{2}$ Emotional appeals should not be used when the writers realize that their arguments and evidence will not stand careful scrutiny. ${ }^{3}$

\section{Utilizing the Three Components}

In the proposed magazine, all three components of Aristotle's rhetorical model would be utilized and combined by the article writers. This combination would require careful and self-critical research by the writers to produce logical and factual articles which would also appeal emotionally to the audience. However, the effectiveness of ethos, logos, and pathos alone could be improved by the

$$
\begin{aligned}
& { }^{1} \text { Ibid. } \\
& { }^{2} \text { Ibid., } 80 . \\
& { }^{3} \text { Ibid., } 83 .
\end{aligned}
$$


additional use of more recent discoveries in the field of persuasive communication. The next section of this study presents a few other techniques which writers can use to enhance the effectiveness of their articles.

\section{Establishing Common Ground}

The writers' ability to persuade their audience will be enhanced by writing in a way which implies a similarity between the writers and the audience.

Kenneth Burke said, "You persuade a man insofar as you can talk his language by speech, gesture, tonality, order, image, attitude, idea, identifying your ways with his."

Lucas restates this idea:

You do not persuade listeners by assaulting their values and rejecting their opinions. This only antagonizes people. It puts them on the defensive and makes them resist your ideas. As the old saying goes, "You catch more flies with honey than with vinegar."2

Writers should remember that "people like to listen to what they already have interest in, because they enjoy hearing facts which confirm their beliefs."3 By utilizing and emphasizing ideas, values, and experiences which the writers share with the readers, more readers can be

${ }^{1}$ Ibid., 342.

${ }^{2}$ Stephen E. Lucas, The Art of Public Speaking (New York: Random House, 1989), 322.

33annes, 149. 
attracted to the magazine and its message. There are many doctrines and practices which SDAs hold in common with other Christians which could be employed in the proposed magazine in order to establish common ground with the Zimbabwean Christian audience. If the writers can get their readers nodding their heads in agreement at the beginning of the article, then the audience is more likely to accept the ultimate appeal. ' This method would not only increase the marketability of the magazine, but it would also enhance the magazine's ability to reach the hearts of the audience and open their lives to the power of Jesus Christ.

\section{The "Yes, Yes" Method}

The "yes, yes" method is often used by sales people to persuade prospective buyers. In this technique, the communicator breaks down his appeal into several parts and tries to get a "yes" response from the audience to as many parts of the appeal as possible. The key appeal is reserved for the end of the sales pitch. Once the audience has said "yes" to several parts of the appeal, they are also more inclined to say "yes" to the final and most important appeal. This technique could be used in doctrinal articles in the proposed magazine.

\footnotetext{
${ }^{1}$ Lucas, 322 .
} 
For example, the writer could use the "yes, yes" method to teach Sabbath observance. First, the writer could state Exod 31:13, "Tell the people of Israel to keep my Sabbath day, for the Sabbath is a sign of the covenant between me and you forever. It helps you to remember that I am the Lord who makes you holy" (New Living Translation).

The writer could then ask the readers, "You would like to live a holy life, wouldn't you?" The answer would likely be "Yes." The next two questions, "You cannot make yourself holy çan you?" and "Would you like God to make you holy?" would probably also be answered "Yes."

The writer would then emphasize that God promises to make people holy. Pointing out that.God established the Sabbath as a sign that He can recreate humanity's sinful nature, the writer would then ask, "Wouldn't you like. to acknowledge that only God can make you holy by observing the Sabbath?" This last question would be the most critical one, and some readers who said "Yes" to the previous questions would probably answer "No" to this question. However, this "yes, yes" approach will have increased the overall chances of any reader saying "Yes" to the entire message of the seventh-day Sabbath. 


\section{A Few Changes at a Time}

Human beings are subject to the law of inertia, the tendency of something at rest to stay at rest. Humans do not welcome change because change brings insecurity and uncertainty. Christian writers should recognize that this human tendency makes it difficult to change religious beliefs. The history of the Christian church shows that many people would rather die than change their beliefs. Therefore, writers for the proposed magazine should only suggest a few changes at a time. Larry Niemeyer advises against subjecting individuals. to "too much change in too short a time."1 (1) Such changes, he says, bring in their train shock and shattering distress to the individual. The articles should therefore avoid scaring off the readers by calling for sweeping changes in their lifestyle, beliefs, or habits.

Zannes advises that "persuasion is more effective if we don't ask for too much." ${ }^{2}$ Even if the few suggested changes do not appear to be affecting the audience, writers must also remember that "the effects of persuasion are long

${ }^{1}$ Larry Niemeyer, "The Information Super Highway and Christian Response to Knowledge," Perspectives, January $1998,47$.

22Zannes, 125. 
range, and the ideas planted for consideration may be fed by others and eventually grow."1

\section{Conclusion}

In summary, the articles in the proposed magazine will be more persuasive if the writers are aware of ethos, logos, and pathos. The writers should carefully read and research whatever subject on which they wish to write. Articles which reflect sound reasoning (logos) will enhance the credibility (ethos) of the writers. The writers should also appeal to the emotions (pathos) of the readers but must be careful to avoid emotionalism. Other techniques the writers could employ are establishing common ground with the readers, using the "yes, yes" method, and suggesting only a few changes at a time.

The persuasion techniques suggested above do not guarantee a widespread acceptance of the proposed magazine's message. However, writers who utilize these methods will be the most effective in spreading the message of Jesus Christ to the Zimbabwean people and in increasing the marketability of the proposed magazine.

\footnotetext{
${ }^{1}$ Hasling, 78 .
} 
CHAPTER 6

MARKETING

\section{Introduction}

The marketing of the magazine is one of the most important operations in the production of a magazine. The message that is published will benefit nobody unless it reaches the people. The marketing department tries to ensure that the published magazine reaches as many people as possible. Poor marketing results in small circulation, which can cause the magazine to collapse.

However, the task of marketing is not the sole responsibility of the marketing department. Everyone. involved in the making of the magazine, including the writers, designers, and the editor should constantly ask themselves how their contribution will make the magazine more appealing to the reader. They should constantly ask themselves how their work meets the readers' needs. If marketing is used as a guiding philosophy for writers, editors, designers, and everyone else involved in producing the magazine, then the marketing department becomes critical 
in fulfilling our mission. It becomes the central focus of the other departments of editing and funding. The relationship among the departments, which was compared to the three legs of a stool by Roland Wolseley in chapter 1 , will become clearer in the following section, which defines marketing.

\section{Definitions of Marketing}

Today, marketing is no longer viewed just as selling and promoting. These are important aspects of marketing, but more and more the center of emphasis in marketing is shifting to knowing what to produce.

Peter F. Drucker, regarded as one of the foremost theorists in modern management, says:

There will always, one can assume, be a need for some selling. But the aim of marketing is to know and understand the customer so well that the product or service fits him and sells itself. Ideally, marketing should result in a customer who is ready to buy. All that is needed then is to make the product or service available. ${ }^{1}$

Two other marketing theorists, Regis McKenna and Siri Espy, have also defined marketing in concepts which are related to Drucker's definition. McKenna sees the goal of marketing as serving the customer's real needs. He also

${ }^{1}$ Peter F. Drucker, Management: Tasks, Responsibilities, Practices (New York: Harper and Row, 1985), 64-65. 
sees it as building relationships with customers. ${ }^{1}$ Espy defines marketing as "a means of identifying what is wanted and needed." 2 Kevin Miller, editor of Christian History magazine, highlights the audience's needs in his discussion of magazine marketing by stating that "marketing begins not with the editor but with the audience."3

All marketing theorists cited above agree that the goal of marketing is to understand the customers' needs and satisfy them. This role, as chapter 3 explained, is played by the editor who studies the readers' needs and selects articles which address them. The aspect of building relationships with customers is also fulfilled by the editor. As detailed in chapter 3, the editor meets with readers and tries to involve them in the production of the magazine. This creates a sense of participation and ownership, which is vital in the marketing of the magazine.

By examining the definitions of marketing presented above, it is easy to see that the editor, and not the marketing director, plays the most pivotal role in marketing the magazine. However, the marketing department is also

\footnotetext{
${ }^{1}$ Regis McKenna, Relationship Marketing (New York: Eddison-Wembly Pub. Co., 1991), 6 .

${ }^{2}$ Siri Espy, Marketing Strategies for Non-Profit Organizations (Chicago: Lyceum Books, 1993), 2 .

${ }^{3}$ Kevin Miller, 3 .
} 
essential to the magazine's success. As with the editorpublisher, the financial goal would be to enlist a volunteer to operate as marketing director while on the payroll. of one of the Zimbabwean conferences or the union. A possible volunteer could be the union or conference publishing director who could coordinate different aspects of the literature ministry, both production and marketing, throughout his assigned territory.

The rest of this chapter deals with the aspects of marketing, which involve selling and promoting the magazine.

\section{Methods of Selling}

Marketing a magazine is a complex business. No specific marketing strategy can be universally successful. It is therefore important that the proposed magazine's marketing department try several methods to discover which one works best for the target audience.

There are two ways of selling magazines: single-copy and subscription selling. The following sections discuss these sales methods.

\section{Single-Copy selling}

Single copies of a magazine can be sold through bookshops, newsstands, and churches. The task of distributing copies of the proposed magazine to numerous 
bookstores and newsstands could pose great challenges. The Zimbabwean Post Office is expensive and could be unreliable. Two previously mentioned African publications, step magazine and Today in Africa, discovered an easier way to distribute their magazines.

Step's marketing department arranged to pay the Daily Nation, East Africa's largest newspaper, to distribute step along with their newspaper. The Daily Nation newspaper also collects money from the vendors after the magazines are sold. ${ }^{1}$

The publishers of Today in Africa, which is published in Kenya, proposed a similar arrangement to standard's circulation department, requesting them to distribute the Kenyan magazine for a fee. When the standard started distributing the magazine, sales of Today in Africa shot up by 225 percent within two issues. ${ }^{2}$ In a short time the sales went up by 375 percent. The standard collects the money from the street vendors on behalf of Today in Africa. Njoroge, the editor of Today in Africa, suggests that a publisher who wants to sell his magazine on newsstands

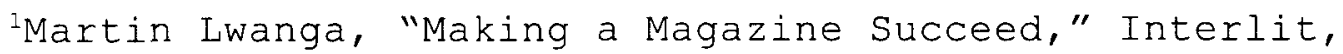
December 1995,18 .

${ }^{2}$ Mwaura Njoroge, "Distribution That Works," Interlit, June 1995, 18 . 
should seriously consider distributing through a newspaper with an established circulation network. ${ }^{1}$

In Zimbabwe there are dozens of daily and weekly newspapers with a wide distribution network. Many of them are struggling financially, and a contract for them to distribute the proposed magazine along with their newspapers for a fee would probably be accepted. The newspaper which distributes the magazine would also collect the money on behalf of the magazine. This system of distribution would ease the collection burden for the publisher and also enable the magazine to sell on newsstands throughout the country. This could result in high circulation, which in turn would reduce the average cost of producing the magazine. This "chain reaction" would strengthen the financial base of the magazine, making the project viable, and most important of all, this system would reach more people with the gospel message.

In Zimbabwe, the publishing department of the SDA church has book shops in all of the major cities. It should be possible to negotiate with these bookshops to sell issues of the proposed magazine in return for a commission. It should also be possible to arrange with other Christian bookstores and even non-Christian bookstores to carry the

${ }^{1}$ Ibid. 
proposed magazine on their shelves. Most single-copy sales would be done through retail outlets.

Retail outlets which sell single copies would be very important in the marketing of the envisioned magazine. AfriTell and Full Life magazines were sold only through retail outlets by single-copy; these two magazines did not offer subscriptions, a process which is described later in this chapter.

Transition from single-copy to subscription selling

While I was the editor of Full Life, readers wrote letters to the magazine expressing how they appreciated some articles published in the magazine. Many of these readers could have been turned into subscribers. Most people will subscribe to a magazine only after they have read it first.

In 1977, a study on how people buy magazines in America revealed that almost 50 percent of readers who were current subscribers to a magazine had bought the magazine as a single copy the previous year. ${ }^{1}$ Although no recent studies have been made to detail the subscription practices of people in Zimbabwe, this American study indicates that single-copy selling could be successfully used as a

${ }^{1}$ Lieberman Research, How and Why People Buy Magazines (New York: Publisher's Clearing House, 1977), 80. 
transition to subscription selling for the proposed magazine.

The challenge for the marketing department of the proposed magazine would be to get as many single-copy buyers as possible onto the subscription list. This effort would be worthwhile because, as the following section describes, there are several advantages for the reader and the publisher in subscription selling.

Although a large number of magazines could be sold as single copies through retail outlets, selling through subscriptions, which would contract readers to pay for a certain number of issues ahead of production, would have several advantages over the single-sales method. The advantages of subscription selling are discussed below.

\section{Advantages of subscriptions}

Increased circulation

A national study of the consumer market for magazines, conducted by Lieberman Research, Inc., discovered that subscription sales outnumber single-copy sales three to two. In order to boost sales and enhance viability of the proposed magazine, the subscription department would need to develop strategies to gain subscribers. ${ }^{1}$

\footnotetext{
${ }^{1}$ Ibid. , 63.
} 
Regular readers

Subscription buyers are more likely to read the magazine on a regular basis than single-copy buyers. Subscribers do not miss issues during their subscription period, so they are more likely to read them. However, Lieberman's research shows that single-copy buying is a sporadic activity. Thirty-two percent of single-copy buyers purchase only one or two issues a year. ${ }^{1}$ This means the proposed magazine would not have as strong of an impact on its single-copy readers since they would not read it on a regular basis.

Magazine commitment

Studies show that readers who subscribe have a higher level of commitment to a magazine than single-copy buyers. They find the magazine more enjoyable and more informative than single-copy buyers do. Also, subscribers generally have a higher overall opinion of the magazine. ${ }^{2}$

Intra-family reading

The goal of any publisher of a religious magazine is to reach as many people as possible with the gospel message.

\footnotetext{
${ }^{1}$ Ibid. , 65 .

'2Ibid. , 73.
} 
Subscriptions tend to multiply the readership of a magazine, thereby increasing the reach of gospel truths.

Assessments of the number of people in a household who read a magazine besides the original buyer have revealed that the readership of subscribed magazines is more likely to be extended among family members than that of magazines bought at retail outlets. Spouses are twice as likely to read a magazine which came through subscription than they are to read a single copy bought at a retail outlet.

The publisher who exclusively sells magazines through retail loses all the advantages that come with subscription sales. The secret to success in magazine sales is to employ both methods of selling to reach more people. The following section provides details on various ways by which the proposed magazine could attract and enroll subscribers.

\section{Acquiring Subscribers}

The following methods would be used to enroll subscribers for the proposed magazine: (1) literature evangelists, (2) direct mail, (3) advertisement, (4) referrals, and (5) organizational ties. The following sections of the study discuss each of these methods. 
Literature evangelists

In the Zimbabwe Union Conference (which is an administrative territory of the SDA church made up of three local conferences in Zimbabwe), one of the traditional methods of marketing Adventist literature has been through the use of literature evangelists. Literature evangelists (L.E.S) are individuals who sell literature from door to door and are remunerated on a commission basis. L.E.s in the Zimbabwe Union Conference have realized steady growth in their literature sales since 1993. Table 1 shows the growth of literature ministry in Zimbabwe since 1993.

Table 1. Growth of Literature Sales by Literature Evangelists in Zimbabwe Union Conference, 1993-1997.

\begin{tabular}{lccr} 
Year & L.E.S & No. Books Sold & \multicolumn{1}{c}{ Sales } \\
\hline 1993 & 100 & 10,620 & \\
1994 & 120 & 15,037 & $1,510,339$ \\
1995 & 150 & 15,125 & $2,320,853$ \\
1996 & 200 & 22,594 & $3,607,039$ \\
1997 & 200 & 37,024 & $7,034,759$
\end{tabular}

Source: Zambezi Union Publishing Report, 1993-1997.

The growth in the literature sales reflected in Table 1 shows that using L.E.'s to sell the proposed magazine may be one of the most viable marketing options. 
The literature evangelists would be encouraged to market the magazine by getting yearly subscriptions. For every year's subscription sold, the literature evangelists could be entitled to keep 45 percent of the retail price, as they currently do with other books they sell. To increase incentive for literature evangelists to sell the magazines, the literature evangelists could be entitled to 45 percent of the subscription cost for as many years as the subscriber maintains the subscription. In this way, each subscription would be a potential long-term "investment" for the literature evangelists, which would encourage them to sell the magazine as vigorously as they sell their other literature.

Using literature evangelists to enroll subscribers has one major advantage: a professional L.E. can reach many homes in one night and talk to prospective readers about the magazine. In salesmanship, it is this face-to-face interaction between the customer and the salesperson which prompts a purchase. This is why many sales people and L.E.'s in Africa and elsewhere have relied on the canvassing method to sell their products for decades. 
Direct mail

In this method, the publisher would mail brochures to targeted homes. This is the major method used by Western publishers to get magazine subscribers. ${ }^{1}$

The direct mail system has two major disadvantages. First, it would be expensive to mail letters to thousands of homes. Second, the editors of the Harvard Post also say, "A successful direct mail campaign is thought to be one that produces a three percent or greater response." 2 If 3 percent is considered a success, this means that the potential response may not be worth the time, effort, and money of a direct mail method. This method's success remains to be determined in Zimbabwe.

Inside-space advertisement

Cards bound inside the magazine could be used to advertise the magazine. This method would be convenient to both the publisher and the subscriber: The publisher would not have to pay to advertise, and the subscriber would simply have to mail the card and pay for the subscription.

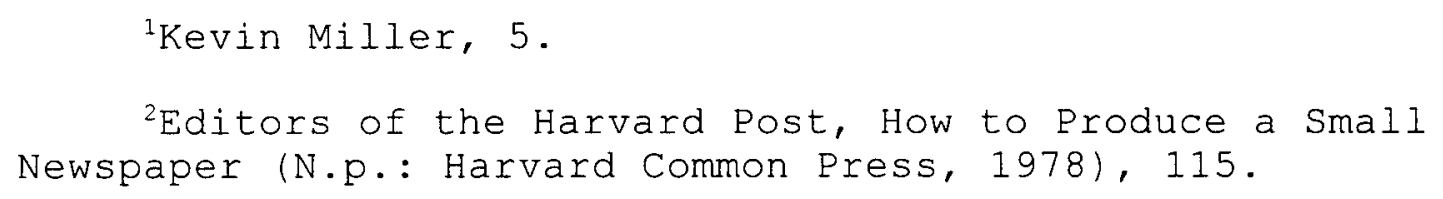


Referrals

In this method, the publisher would request current readers to submit the names of people who would be likely to enjoy the magazine in exchange for small gifts for the readers, such as free Bibles. ${ }^{1}$

Organizational ties

This method would involve the publisher giving an offer, such as four months' free subscription to the proposed magazine, to Christian college students in exchange for names of potential subscribers. This means that the publisher would initially have to sacrifice a substantial amount of money in order to later acquire more subscriptions. The majority of magazine publishers are willing to pay the price of a subscription in order to find another subscription. ${ }^{2}$ The cost can be recovered if the original and new subscribers continue to renew their subscription.

Renewing current subscribers

While the proposed magazine should vigorously search for new subscribers, equal efforts should also be made to retain current subscribers. In 1990, Harold Myra, publisher

${ }^{1}$ Kevin Miller, 5 .

${ }^{2}$ Ibid. 
of Christianity Today, estimated that it cost $\$ 17.50$ to find a new subscriber, while it cost only $\$ 2.00$ to retain a current one in the U.S. ${ }^{1}$ The actual amount that a publisher in Zimbabwe could save by renewing subscribers is uncertain, but it would seem logical to infer that there would be significant savings there as well.

Miller calculates that magazines with renewal rates of 70 percent are healthy, while those with less than 40 percent are headed for disaster. ${ }^{2}$ So, from a financial point of view, it makes sense to try to retain current subscribers.

Richard Horne has suggested the following measures to retain current subscribers: (1) accurate records, (2) appropriate marketing methods, and (3) anticipating readers' needs. These solutions are briefly discussed in the following section.

Accurate records

Record keeping would need to be accurate in order to retain current subscribers. Names and addresses of subscribers would need to be checked and updated monthly.

${ }^{1}$ Ibid.

${ }^{2}$ Ibid. 
Richard Horne provides a good example of the type of information needed in the subscription records:

Name/address of subscriber; phone number; type of subscription (gift, direct mail, etc.); number of copies sent with each issue; first issue number (issue at beginning of subscription); renewal issue number; and final issue number. ${ }^{1}$

Without accurate records, subscribers would not receive efficient service. As a result, many might not renew their subscriptions. To ensure accurate record keeping about the proposed magazine's subscribers, a part-time secretary would be employed. A computer, which would facilitate record keeping and also assist the magazine in other ways, would be purchased.

Appropriate marketing methods

Apart from accurate record keeping, appropriate marketing methods are also needed to retain current subscribers. Richard Horne counsels magazine publishers to never overestimate the reader's loyalty. Even long-time subscribers need to be re-convinced that the magazine is worth it before they will renew their subscription.

Offering discounts on the proposed magazine's cost could revive interest in the readers. However, care would

${ }^{1}$ Richard Horne, "Three A's for Reader Retention," Interlit Imprint, unit 4, 1994, 24. 
need to be taken to ensure that the production costs would be covered by the special subscription price. ${ }^{1}$

Staying in touch

Staying in touch with the reader is an effective way of retaining a current subscriber and can be accomplished in several ways. First, a computer printout could be stuck inside the magazine with a reminder such as "You have only two issues left in your subscription." Later, another printout could inform the reader, "This is the last issue of your subscription. Renew now so you may continue to be on our mailing list." If no response comes, a postcard describing the upcoming issues could be mailed to the subscriber. Readers could be asked if they would miss the magazine when the subscription ended. The publisher could then suggest ways to help the reader re-subscribe. ${ }^{2}$

The publisher could also suggest creative ways for readers to use the magazine, such as birthday or Christmas gifts to someone.

${ }^{1}$ Ibid.

${ }^{2}$ Ibid., 25 . 
Making renewal easy

The publisher should seek ways to make renewal easy. He/she should anticipate the readers' questions about renewing their subscription and find ways to answer them.

Renewal coupons which would explain the terms of subscription and the method of payment could be used. The coupons could be folded into a self-addressed, stamped envelope to make it easy for busy people to subscribe without going through unnecessary procedures. ${ }^{1}$

\section{Other Marketing strategies}

The first issue

One of the best marketing strategies in magazine marketing is to ensure that the first issue is a knockout. The first issue introduces the magazine to the market, and the first impressions, whether good or bad, which the premier issue creates in the market are difficult to change over a long time.

The first issue of the proposed magazine ought to have the best possible design and layout since it would be a promotional issue. ${ }^{2}$ Also, the featured articles ought to be

${ }^{1}$ Ibid.

${ }^{2}$ Editors of the Harvard Post, 113. 
on subjects of intense interest to the prospective subscribers.

Publication frequency

In order to test the market acceptance of the magazine, a wise choice would be to publish it quarterly at first. Later on, as the magazine gains popularity, the editor could then decide to publish bimonthly. By beginning on a quarterly basis, the new editorial staff would have more time to cope with their new responsibilities and the writers-in-training would have more time to develop new articles.

Complimentary copies

Prospective subscribers must have an opportunity to see. a magazine before they choose to subscribe to it. This would mean that most of the copies of the proposed magazine's first issue would probably be given out to the target audience as complimentary copies. ${ }^{1}$

The complimentary copy could be mailed to the prospective subscriber or it could be delivered by a doorto-door salesperson. Two things would need to be clear to the prospective readers: (I) how many free issues they would receive, and (2) how they could subscribe to the magazine.

\section{${ }^{1}$ Ibid.}


A large subscription advertisement with a removable subscription mail-in form attached to it could be placed in a prominent position in the magazine in order to explain the subscription procedure. ${ }^{1}$

Everyone who received a complimentary copy could be contacted afterwards by phone or by a door-to-door salesperson. They could be asked what they thought about the magazine and if they would like to subscribe. ${ }^{2}$ It would be also important to listen to the prospective subscriber's suggestions on how they think the magazine could be improved.

\section{Pricing}

Whether the sales method is by single sales or by subscription, the pricing of the magazine should be given careful study. The publisher should avoid overpricing, which could lead to a decline in sales. The publisher should also avoid underpricing because this would diminish revenue and jeopardize the livelihood of the magazine.

The following components would need to be accounted for when determining the price of the proposed magazine: (1) the cost of producing the magazine, including the cost of paper,

\footnotetext{
${ }^{1}$ Ibid. , 114

${ }^{2}$ Ibid. , 115 .
} 
ink, salaries, etc.; (2) the commission required by bookstores or literature evangelists; (3) inflation over time, for subscription prices; (4) the price of competitor magazines. The above criteria for setting prices would be combined with two other methods described below.

Perceived value pricing

In this method, the price is set "on the basis of the product's perceived value." ${ }^{1}$ The publisher would try to determine what the readership thinks about the magazine, and how eager they would be to obtain the magazine. The editor and the marketing director would personally interview readers to obtain this. vital information. ${ }^{2}$

Value pricing

In this method, the publisher would charge a low price for a high-quality product. The customers would realize that they could purchase a good product for a real bargain, and this method could lead to high volume of sales, which would in turn compensate for the low price. ${ }^{3}$

\footnotetext{
${ }^{1}$ Martinelli, 175 .

${ }^{2}$ Ibid.

${ }^{3}$ Ibid.
} 
The major advantage of this method is that more issues of the proposed magazine would be sold, allowing more people to be reached with the message.

\section{Conclusion}

In summary, this chapter investigated the marketing philosophy and strategies for the proposed magazine. All members of the magazine production would need to approach their jobs from a marketing viewpoint which would try to understand and satisfy the readers' needs.

The proposed magazine could be sold through retail outlets in single copies and also through subscription sales. The section on subscription sales described various methods to attract and enroll subscribers. This chapter also discussed how the publisher could encourage renewal subscribers and concluded with a discussion on appropriate pricing methods for the proposed magazine.

If correct marketing strategies are followed by the proposed magazine's editor, writers, designers, and other employees, the magazine circulation could be quite farreaching, spreading the message to more people. The financial base of the magazine could also be strengthened by- the marketing techniques which this chapter detailed. 
CHAPTER 7

FUNDING

\section{Introduction}

The task of raising funds for the proposed magazine would be faced by two main obstacles: the state of the Zimbabwean economy and the lack of confidence among the SDA Division and Union leaders in the success of another magazine project.

\section{State of Zimbabwe's Economy}

Although Zimbabwe has one of the strongest economies in Africa, as of late, the country's economy has been on a downward slide. In 1998, inflation was an alarming 32 percent. ${ }^{1}$ Wages have skyrocketed and the prices of goods and services have shot up in Zimbabwe. As a result, the cost of producing the proposed magazine would likely be staggering

Without adequate funding, it would not be possible to produce a high-quality magazine which would appeal to the

"High Interest Rates Hit Property Market," The Herald, 22 October 1998,5 . 
prospective readers. If, on the other hand, funding was adequate, qualified staff could be hired and a high-quality magazine could be published.

\section{Church Leaders' Lack of Confidence}

The normal way of funding a magazine such as the one under discussion would be through the SDA church organization. Laesso D. Raelly, president of the Eastern Africa Division (EAD), feels that there is a critical need for a magazine such as the one proposed in this study, not just in Zimbabwe but in the whole EAD. However, when asked about funding for the magazine, he said the SDA church would not be able to fund it. ${ }^{1}$ Pastor Machamire, president of the Zimbabwe Union Conference, also expressed the need for an evangelistic magazine in his Union but was noncommittal about funding

The main factor which seems to have dampened enthusiasm for an evangelistic magazine in the Adventist church in Zimbabwe and elsewhere in Africa is the sad history of previous evangelistic magazines in Southern Africa, such as Afritell, Signs of the Times, and Full Life. Since these magazines have already been discussed at length in earlier 1997 .

${ }^{1}$ Laesso D. Raelly, interview by author, 18 November 
chapters of this study, only a brief summary of their publishing histories is given here.

In 1984, Afritell magazine was launched in Harare. This magazine was intended to circulate on the entire African continent and was funded through the General Conference of Seventh-day Adventists. The first two issues generated a great deal of enthusiasm in the magazine. Unfortunately, the foreign editor left, and the editor who succeeded him lived in Cote de Ivoir in West Africa. Afritell's publishing house was transferred from Harare to Abijan in west Africa to be closer to the editor's residence, and distribution of Afritell to the people of Zimbabwe subsequently ended.

The church leaders in Zimbabwe remember this poor experience with Afritell. The leaders are also aware that the South African Signs of the Times was a financial burden to the South African Union. In the 1980s, the South African Union tried various methods to keep the magazine alive. Finally, in 1989, the South African Union decided to dump the magazine to avert running into serious debt. This history would be in the minds of the leaders if someone were to suggest starting a new magazine publication in Zimbabwe. 
Also, from 1991 to 1992, I served as editor for Full Life magazine in zimbabwe. The project was forced to stop after only three issues when I left Zimbabwe to study in the USA. All these unsuccessful magazine publication attempts have weakened support for another initiative. It is therefore unlikely that the idea of starting a new magazine would be greeted with support by the church leaders in zimbabwe.

\section{Alternative Sources of Funding}

Since funding for the magazine would be unlikely to come from the church organization, the prospective publisher of the magazine would need to look elsewhere for funding. The most logical source of funding would seem to be the people who would benefit from the magazine: the church members. Therefore, a plan to raise funds from church members is discussed below.

\section{Church Members}

Past experiences

In 1991, the East Zimbabwe Conference launched a small missionary magazine called Full Life. I edited this magazine. The funds for the project were donated by an Australian church member who was approached by our conference treasurer, also an Australian. The treasurer and I played a key role in planning the project. We kept the 
conference president and secretary informed about our progress.

Just after the first issue rolled off the press, we discovered that very little money was coming from the Australian donor. It became apparent that we could not sustain the project on foreign funding.

The conference did not have money for the magazine in its budget. Desperate to keep Full Life going, we began to solicit funds from church members. Our efforts came to no avail. We did not get a single donation from the members. In retrospect, the magazine's funding efforts failed because the church members were not mobilized to own and support the project from the beginning. The next section describes the ways by which the proposed magazine could ensure adequate funding from church members.

Obtaining goal ownership

The most vital step would be to obtain goal ownership among the church members. Instead of restricting the magazine's planning to a small group of people, as many church members as possible should be involved. A discussion on the role of a religious magazine in the fulfillment of the Adventist mission to evangelize the world could be started with church members. The church members could be 
led to the point where they would begin to say, "We must have our own evangelistic magazine."

Once the church members saw the need for the magazine, the discussion could go to the next level. The members could be guided in planning how the magazine could be funded and marketed. Church members could then feel proud to say, "This is our magazine." They could rightfully say, "This is what we plan to do," rather than, "This is what the conference or pastor plans to do."1 By involving church members from the planning stage, the magazine could help to ensure future support from the church members: "People feel committed to what they help develop and the planning stage is fun. . . The more people you include in the planning, getting them to agree on needs and solutions, the greater the group's motivation for the project."2

Benefits to church members

Before the church members get involved, the reasons why they should participate should be clear. The church members should finance the magazine for the following reasons: (1) the church members could use the magazine for their own

${ }^{1}$ Carl F. George and Robert E. Logan, Leading and Managing Your Church (Grand Rapids, MI: Fleming H. Revell, 1992), 136.

'Ibid. , 137. 
spiritual growth, and (2) they could use the magazine as an evangelistic tool. "Getting money from the people who need your organization (or project) is the foundation of all grass roots fund-raising. It is the most dependable, renewable and democratic way to raise money."I

Once the church members decide that they need the magazine and are willing to fund it, meetings could be held to set up a fund-raising committee, whose main duties are discussed in the following section.

Fund-raising committee

The fund-raising committee would be set up to do the following:

1. Plan the program

2. Make the budget for the magazine

3. Make fund-raising strategies

4. Provide an example by making pledges themselves.

The committee could be headed by people who are competent fund-raisers. The editor and volunteers from the conference or union accounting departments could also be part of the committee. The committee would aim to inspire the confidence of potential donors by looking like a winning team.

'Joan Flanagan, The Grass Roots Fund-Raising Book (Chicago: Contemporary Books, 1982), 47. 
Talking to potential donors

Flanagan advises that fund-raisers should be prepared to explain the following:

1. What they intend to do (in one sentence)

2. How the project would be sustained once it gets off the ground.

3. Why they think the project would succeed.

4. What would be done with donor contributions.

A time frame for the action to implement the project. ${ }^{1}$ The kinds of donations the proposed magazine could seek from the church members would be: one-time donations to be used as start-up funds, and gift subscriptions for non-members. A brief explanation of each donation type is given below.

Start-up funds

The start-up funds should be sufficient to ensure that the magazine is colorful and appealing to the readers from the very start. The exact amount needed could be determined by the printing costs at the time when the project is implemented.

Prospective major donors would need to be identified to raise the start-up fund. For the purpose of this project, a

${ }^{1}$ Ibid. , 97. 
major donor would be defined as any person who donated Z\$1,000 (Zimbabwe dollars) and more to the magazine.

Before the prospective donor would be approached, relevant public information about that person would need to be noted. If that person was paying a mortgage for a house, this could affect how much they would be able to give. It would also be important to note recent purchases, such as a car or a house. This information could help the fund-raiser determine the gift range that the prospective donor could be asked to give. The prospective major donors would be approached individually. The fund-raiser who was best acquainted with the prospective donor would be sent to him or her.

The funds raised from major donors could be supplemented by contributions from smaller donors. For the purpose of this paper, a small donor would be defined as anyone who donated less than $\$ 1,000$. The small donors could be addressed as groups in their churches. They would be informed that the donations they were being asked to give would be one-time donations. They would also be told that once the magazine starts circulating, they would be requested to support it by paying for their own subscriptions as well as that of non-members. 
Subscriptions for non-members

One of the fund-raising methods used by the South African Signs of the Times is to ask church members to pay for non-members' subscriptions as well as for their own magazine subscriptions. According to Signs editor Eric Webster, 186 churches participate in this project. The result is that their circulation has reached $15,000,1$ and the project is self-sufficient. This is an impressive record for a magazine which targets a readership of south African whites, who are known to be generally secular.

This payment method might inspire more people to give. People prefer to give to people and not just to a project. Church members could be asked to subscribe one year's subscription as a birthday or Christmas present to someone. The editor could personally visit churches annually to promote these gift subscriptions for non-members. Each church could also have a coordinator to follow up and encourage church member participation.

This payment method could help to increase the volume of sales, which in turn would increase revenue. However, once the proposed magazine has several thousands of

\footnotetext{
${ }^{1}$ Eric Webster, telephone interview by author, 19 october 1998.
} 
subscribers, it would be easier to approach advertisers for additional funding.

\section{Advertisers}

Advertisers want to be assured of a large number of dependable readers before they consider placing their advertisements in a magazine. The audience of the magazine should also be the same people the advertiser is targeting. The advertisers which could be approached to fund the proposed magazine would be those who do business with Adventist institutions or church members, which would be members of the magazine's audience. For example, the SDA church in Zimbabwe runs 96 schools, most of them with an enrollment of more than 600 students. ${ }^{1}$ In Zimbabwe, many departmental stores compete to supply. school uniforms to schools. Book suppliers also compete to supply textbooks and stationery to schools. The SDA schools alone provide an annual multimillion-dollar business to uniform suppliers and textbook suppliers. These suppliers could be sold advertising spaces in the magazine. Some of their advertisements could also be used as page fillers. To convince the potential advertisers that the proposed magazine would be hitting their potential markets, the

\footnotetext{
${ }^{1}$ Patrick Mazani, interview by author, 5 August 1998.
} 
publisher could ensure that the principal of every SDA school would receive a free subscription. The publisher could also show the potential advertisers the monthly "dummies" (tentative outlines of future magazine issues) and try to sell advertisement space for the whole year.

\section{Conclusion}

In summary, this chapter pointed out two financial challenges which would face the proposed magazine: Zimbabwe's economic situation and the unlikelihood of receiving funding from the SDA organization. In order to overcome these obstacles, the proposed magazine would need to search for alternatives involving church member support and advertising revenues.

Initially, the church members could provide sufficient funds for the magazine's start-up costs. However, once the subscription base of the magazine is large enough, advertisers could be interested in promoting their products through the magazine. This would provide additional financial support, especially if the magazine is able to reach the advertisers' target audiences.

With careful fine-tuning and guidance by volunteers from the conference or union accounting departments, this funding plan could bring much-needed revenue to the proposed 


\section{9}

magazine project and set the magazine on the path to selfsufficiency. 
CHAPTER 8

\section{DEVELOPING SELF-SUFFICIENCY}

\section{Introduction}

As discussed in chapter 7 , the proposed magazine could not be entirely dependent on subsidy from the church organization or even on contributions from church members. In times of financial difficulties, a magazine would be regarded as a luxury, and funds allocated to the magazine by church organization and members would likely be diverted to other areas.

In order to diminish reliance on the church for funding, the ultimate financial goal of the proposed magazine should be to achieve self-sufficiency. Many development agencies want to ensure that "self-sufficiency and ultimate independence are the ultimate long term goals [of an organization]. They argue that a series of subsidies and grants are bad because they lead to dependency and a feeling of inadequacy." 1 $1996,4$.

${ }^{1}$ Alec Gilmore, "Publish for Profit," Interlit, March 
Self-sufficiency means that "the organization's products generate enough income to allow the organization to meet its expenses and continue to operate beyond the present point."I Self-sufficiency is a process that usually takes a long time to achieve, but it is a worthwhile state to be strived for by the proposed magazine:

Self-sufficiency means being able to take care of yourself; you are able to meet your own needs now and expect to be able to rely on yourself for your future. In publishing, self-sufficiency means that the organization's products generate enough income to allow the organization to meet its expenses and continue to operate beyond the present point in time. ${ }^{2}$

\section{Advantages of Self-Sufficiency}

Self-sufficiency would offer a couple significant advantages to the proposed magazine. One advantage would be reduced worries about insufficient funding from outside the magazine and additional concentration on the magazine. If the magazine is self-sufficient, the editors would not need to spend valuable time and energy raising money instead of concentrating on the publishing work. ${ }^{3}$

Self-sufficiency would also make the editorial board independent. If the proposed magazine was dependent on the

${ }^{1} V i s i o n$ for Self-Sufficient Publishing (Colorado springs, CO: Cook Communication Ministry, 1996), 4 .

${ }^{2}$ Ibid.

${ }^{3}$ Ibid., 11 . 
church organization for funding, its editorial policy could be dictated by those who funded it. Self-sufficiency would place control of the editorial policy and goals directly in the editor's hands.

\section{Goals of Self-Sufficiency}

The long-term goal of self-sufficiency is making a profit. However, at the present rate of inflation in Zimbabwe, that goal could be unattainable for the proposed magazine. The goal of self-sufficiency could therefore be considered to have been reached if the magazine's income merely meets and supports its expenses. ${ }^{1}$

\section{Strategy for Self-Sufficiency}

Self-sufficiency would take place in stages for the proposed magazine. First, the publisher would need to determine to solve his or her publishing problems:

Problem solving is built on a decision to do just that-solve problems using the resources and strategies available in your context. Focus on developing creative approaches to common problems, rather than assuming outside help is needed. ${ }^{2}$

$$
\begin{aligned}
& { }^{1} \text { Ibid., } 6 . \\
& { }^{2} \text { Ibid., } 5 .
\end{aligned}
$$




\section{Count Costs}

The first step towards self-sufficiency would be to count all the costs involved in producing the magazine. Some of the costs which would need to be taken into account are: (1) salaries or outside fees, (2) value of volunteer labor, (3) office overhead, (4) equipment maintenance, (5) value of donated goods, (6) advertisement costs and promotion, (7) printing and binding, (8) warehouse costs, (9) transportation costs, (10) royalties to authors, (11) order processing, (12) printing, and (13) paper costs.

\section{offer Companion Services}

Some magazine publishers generate income by printing greeting cards, bookmarks, posters, and calendars which may sell wel1.2 The proposed magazine could offset a portion of the magazine's production costs by printing products which are in local demand.

\section{Manage Finances}

Self-sufficiency would need to be achieved by funds from selling the magazine. The revenue from the magazine would be compared with the total amount needed to produce the magazine. The next step would then be to figure out how

\footnotetext{
${ }^{1}$ Ibid. , 8 .

${ }^{2}$ Ibid., 7 .
} 
far the magazine is from breaking even. The publisher could then establish how much increase is needed in sales to close the gap between the sales and the costs. ${ }^{1}$ Inflationary effects would need to be taken into account.

\section{Reduce Costs}

One very effective and logical way to achieve selfsufficiency would be to reduce costs in the proposed magazine enterprise. The publisher could reduce the average costs, and she could also hire qualified staff and purchase the right equipment. The next section of this study discusses each of these overall cost-reducing methods.

Reducing average costs

The average cost is the cost of producing each individual unit. The average cost is calculated by dividing the total costs by the number of units produced. The average cost decreases when production increases up to a certain point. If the publisher reduces the average cost, the magazine can be sold at a reduced price, thereby making it more competitive on the market.

However, before the publisher could decide to increase the circulation, market studies would need to be performed in order to establish the existing demand for the magazine.

IIbid. , 14 . 
If demand is sufficient, then the marketing department could seek more subscriptions, negotiate with other bookstores to single-copy sell the magazine, and also pursue other marketing strategies.

The goal of reducing the average costs would be to reach a point at which sales income would equal or exceed the total fixed and variable costs: "Sales = fixed costs + variable costs." 1

Hiring the right staff

The publisher could cut costs by hiring people with the skills which the proposed magazine would need. Often in a small publishing enterprise, employees are required to assume several responsibilities, but they might have the proper skills to perform all their tasks efficiently. For example, a marketing person with strong marketing skills might only have a superficial understanding of production. The publisher might believe that asking that marketing person to also handle production would save money for the enterprise, but that action could prove to be costly in the end.

Continuing this example, a key department like the production department, which must be manned by someone who

Ibid., 25 . 
understands production issues and can communicate with printers well, would suffer if it was under the control of a person who was skillful in marketing but not in production. In the end, the publisher would probably have to pay for mistakes from the production department and could also end up with low-quality products which would be difficult to $\operatorname{sel} 1 .^{1}$

Buying proper equipment

New and better equipment is often expensive to purchase, but the critical question to ask is, what is needed? For example, how much could be saved in the long run by purchasing a computer and doing desktop publishing? If the eventual benefits of purchasing new equipment outweigh the spending of money, the publisher could reduce overall costs for the magazine by buying new equipment and putting it to good use.

\section{Express Goals}

Once the publisher decides on the magazine's methods for achieving self-sufficiency, it would be very important for her to express those goals in writing. The objectives for reaching self-sufficiency could be stated using specific language to outline the course of the proposed magazine over

\footnotetext{
${ }^{1}$ Ibid., 15.
} 
the coming years. "Specific words, especially verbs, will challenge you to reach your final goal." ${ }^{1}$ If a publisher has goals in circulation, the use of active verbs like "increase" circulation will have an impact on actions. ${ }^{2}$ Along with the goals for self-sufficiency, the publisher would also need to "set guidelines for [achieving] the result [the magazine is] aiming for." ${ }^{3}$

The following example illustrates the concept of expressing the goal and the indicator of reaching that goal: "Increase circulation by $40 \%$ over the next two years." The stated objective is measurable because an indicating guideline is included with the objective. This makes it easy for the publisher to be able to judge when the objective has been achieved.

\section{Support Short-Term Strategies}

An effective way of ensuring that an expressed longterm goal continue to be sought after is to detail how and when actions which support that goal could be accomplished."

\footnotetext{
${ }^{1}$ Ibid. , 19.

${ }^{2}$ Ibid.

${ }^{3}$ Ibid.

${ }^{4} \mathrm{Ibid}$
} 
This can be accomplished by utilizing short-term goals. In short-term goals, the focus is on the smaller steps to be taken to achieve the long-term goal of self-sufficiency. The large goal is broken down into smaller, manageable, and specific activities. ${ }^{1}$

If, for example, the long-term goal of the proposed magazine is to reach self-sufficiency, then some logical short-term steps could be designed to move the magazine towards that goal. One short-term step could be to aim for increased circulation. Circulation could be increased by appointing twenty sales agents for the magazine over the next two years. Also, agreements could be negotiated with five to ten stores over a certain period of time.

"With a set of short-term steps before them, staff know. how they should be using their time."2 As the short-term objectives are achieved, the publisher gets closer to the long-term objective. Short-term objectives focus on tasks. These specific actions direct the day-to-day activities of the staff. ${ }^{3}$

\footnotetext{
${ }^{1}$ Ibid.

${ }^{2}$ Ibid. , 21.

${ }^{3}$ Ibid.
} 


\section{Conclusion}

The goal of self-sufficiency for the proposed magazine will probably be one of the most challenging ones to attain. It will not be possible to achieve this goal overnight. The publisher should not be discouraged if the pace of growth towards self-sufficiency is slow. A new publisher must confront and overcome many hurdles on the way to efficiency, and the proposed magazine will have to persevere if it is to eventually reach the desirable state of self-sufficiency. 
CHAPTER 9

SUMMARY AND CONCLUSIONS

\section{Summary and Conclusions}

The goal of this study was to develop a plan to start an Adventist missionary journal for the African people in Zimbabwe.

After an introduction in chapter 1 , the study began with a brief survey of religious magazines circulating in Zimbabwe. A discussion of the only Adventist magazine circulating in Zimbabwe, Signs of the Times, showed that it is not targeted towards African readership. This indicated an urgent need for a distinctly African magazine in the Zimbabwean SDA church.

Following is a summary of the steps which could be taken by a publisher wishing to start the proposal journal.

\section{Finding the Editor}

Perhaps the biggest challenge confronting this project is to find a competent editor.

The editor should not only be a mature Adventist but should also be a writer who is able to articulate the needs 
of African people using figures of speech drawn from their culture. The editor should also be able to generate the enthusiasm of church members to support the magazine.

\section{Developing Writers}

Once a suitable editor has been identified, the next challenge is that of developing a dependable pool of writers.

The editor should ensure that there are African writers capable of writing publishable art nicles for the proposed magazine.

The editor can achieve this by discovering and training indigenous writers before the magazine is launched.

\section{Marketing the Magazine}

After the editor has identified and developed indigenous writers, then he could start negotiating with the literature evangelists and church members about marketing the magazine.

The editor could also start compiling a list of bookshops which are likely to sell the magazine. The actual negotiations could be done when the first issue is published.

When the editor has a reliable pool of indigenous writers, and the marketing strategy in place, then serious 
discussion about funding the magazine could be started with church members.

The editor's will be more likely to win financial support for the magazine among church members if he can show them that the publishing plans are viable.

The church members can give their financial support to the project by paying for their own subscription and making a gift subscription to someone else.

This form of support not only increases the revenue base for the magazine, but also increases its circulation. It also makes it easier to approach potential advertisers because advertisers want to ensure that the magazine which carries their advertisements has a large, dependable readership.

When trained writers are available, when the marketing strategy is in place and the financial plan is worked out, then the magazine could be launched. 


\begin{abstract}
APPENDIX
WRITER TRAINING AND IMPROVEMENT
\end{abstract}

\title{
Introduction
}

Writers' workshops should be held regularly to train and inspire prospective writers. During writers' workshops, tips on writing should be given to the participants. Emphasis will be given to the writing process. Writing is a skill and the best way to master it is by writing often. The following material provides valuable methods and techniques which could be used to educate and improve the writers of the proposed magazine.

\section{Three Tips for Beginners \\ Read Information}

The one who doesn't read' doesn't get read. The prospective writers should read widely in the subject they intend to write. They must read the daily newspapers to keep abreast of events around. They must read'African history and anthropology so that they can understand both the historical and cultural context of the Africans. 
Read Expert Writers

Prospective writers must also read writings of great authors to discover their way with words and facts. Many helpful writing tips can be gained from simply reading and observing other writers' articles.

\section{Be Persistent}

Many times writers must re-write their manuscript several times before they are ready for submission. They will get many rejection slips. Those who keep pressing on will succeed at last.

\section{Finding Article Ideas}

Prospective writers should know how to find article ideas. Every experience in life can spark article or story ideas. The writer needs to use his/her imagination to bring an original angle. It is also vital for a writer to keep a diary. In it he/she must record reactions to events. When he/she reads a newspaper, the crimes, violence, or accidents all may suggest an article. The prospective writer should record his/her reactions in a diary.

A Christian writer will have subjects laid on his heart by the Lord. He is helped and guided by the Holy Spirit in putting the message on paper. The Lord often uses events that are happening around us, books, 
people, etc., to give us ideas to write about. ${ }^{1}$

The writer can also write his/her own conversion experience or someone else's. God's answers to prayer or deliverance in time of danger could also make a good article. ${ }^{2}$ Psychological articles are also very popular. One could do an article on how to overcame boredom or anger or low self-esteem. Family life articles are also in high demand.

\section{Human Interest stories}

"Magazine articles are principally about people, and you cannot operate for long as an article writer without interviewing men and women." 3

One reason why Reader's Digest enjoys such wide circulation is that it is full of human interest stories. "To people nothing is more interesting than people." 40 increase the magazine's readership appeal, a human interest story must be a regular feature. The stories should be about unusual people or events.

The human interest story can be a personal experience

${ }^{1}$ Rex C. Reyes, Writing Tips (Manila, Philippines: OMF Literature, 1993), 27.

${ }^{2}$ Ibid., 27-28.

${ }^{3}$ Gunther, 49 .

${ }^{4}$ Reyes, 30 . 
of the writer or someone else. When the experience is instructive and written vividly, the readers become involved in the experience. Such articles can lead other people to Christ. It is also one of the most effective methods of communicating the gospel. Jesus said to the man who had been cured from demon possession, "Return to your house and tell all that God has done for you" (Luke 8:39).

The goal of the human interest story is to uncover fascinating facts about people. The human interest story goes "behind the scenes of news and events."1 "Human interest stories are presented to make an emotional appeal." ${ }^{2}$

\section{Interviews}

Human interest stories can also be done as interviews. The person to be interviewed must be a well known person whose ideas and views are respected. "The person must also be an authority on the subject of the interview."13 A good interview should instruct, entertain or inspire.

${ }^{1}$ Ibid.

${ }^{2}$ Ibid.

${ }^{3}$ Ibid. 


\section{Guidelines for Interviewing}

Below are guidelines for making good interviews:

1. Make an appointment beforehand.

2. In the preliminary call, tell the person to be interviewed who you are, what you want to interview him or her about and why.

3. Have a list of questions ready, but most of the time people will talk on their own once you get them started.

4. Sit and Iisten as long as the interview does not stray too far from the subject. Avoid interjecting with prepared questions.

5. Try to keep the whole interview friendly and informal. Let it resemble a casual chat. When the interview is too formal, people are reluctant to talk. ${ }^{1}$ Some interviewers avoid interviewing in an office to create a less formal situation. They may do it over a meal. The interviewer avoids taking notes or using a tape recorder. The goal is to get the interviewee relaxed. ${ }^{2}$

6. If you are interviewing for a human interest story, take note of the following: (a) the person's mannerisms. Does the person play with his/her pen or wiggle his fingers?

${ }^{1}$ Gunther, 55 .

${ }^{2}$ Ibid. , 56 . 
(b) Take note of facial expressions, gestures, voice. What are his/her favorite expressions? ${ }^{1}$

These guidelines can help you to make good interviews, but the secret of writing successful interviews is practice. The more you do it, the easier and better it becomes.

\section{Writing Feature Articles}

The following are guidelines to help you to write good feature articles:

1. "Choose a manageable topic. One you have first hand information about." It should not be a topic that is completely new to you.

2. Avoid generalizations. Your facts must be up to date. Research if you need to.

3. Have one aim in your article. You should try to summarize in one sentence what you are trying to say to the reader.

4. Narrow the focus of your article. It is better to wrote on "How I Overcame My Anger" than "How to Overcome Your Problems."

5. Use simple language. "Simplicity is the most natural quality of good prose. A writer if he has something

\footnotetext{
${ }^{1}$ Reyes, 29.

${ }^{2}$ Ibid. , 24.
} 
to say, usually finds that the simplest way of saying it is the best. It is the strongest and most effective."

6. Watch your transitions. "A transition is a group of words that dynamically links two unlike parts or carries the reader through a shift of emphasis or viewpoint."1

Many experienced writers still find transitions a challenge. With practice you can learn to handle transitions in your own way. The following are examples of types of transitions which can help to join sections of an article.

\section{Making Effective Transitions}

\section{Question and Answer}

In this kind you switch from one subject to another by asking a question and then answering it. In the question or in the answer you effectively change the subject. ${ }^{2}$ Here is an example of a question and answer transition: "President Mugabe has ruled Zimbabwe for the last 18 years. Has that improved the welfare of the man in the street? Economic figures reveal that inflation. . ."

\section{Transition Quote}

This is one of the easiest transitions. You just

${ }^{1}$ Gunther, 93.

${ }^{2}$ Ibid., $95-96$. 
change the subject by introducing a new subject in the form of a quote." Here is an example: "President Mugabe has ruled Zimbabwe for the past 18 years. 'Terrible,' said Tekere, 'he has sunk the nation down'."

\section{Double Transition}

Here is an example of a double transition: "In 198.5, only 10 female doctors were in private practice. Male doctors ran most of the private surgeries in Harare but the municipalities are now recruiting female doctors . . ."

\section{Writing the Lead}

The lead is the opening paragraph of a story or article. For most writers, the lead is usually very difficult to write. What are the qualities of a good lead? A good lead does two things well. First, it must grab the reader's attention. It must whet his appetite. A good lead must lure the reader to read on. ${ }^{2}$

second, it must point out the direction the article is taking. "It aims straight at a target, namely the end of the article." 3 A good lead must accomplish these two goals. If it does not, the article will not succeed.

\footnotetext{
${ }^{1}$ Ibid. , 96.

${ }^{2}$ Ibid. 68.

${ }^{3}$ Ibid.
} 
If the lead fails to grab the reader, chances are the rest of the article will not be read. If the lead does not give the reader a definite direction, the readers may get lost or confused. They will stop reading the article. ${ }^{1}$

A good lead also helps the writer. He/she knows what direction the article is going. That makes it easy to write the rest of the article.

Before you write a good lead, you must know what the article is going to say. Know what you are going to prove. Many writers outline their article first before they write the lead. Others map out the general direction of the article, then write the lead. The rest of the article then follows. ${ }^{2}$

Feature Article Leads

There are three basic types of leads for feature articles which will be examined in this section. These three types have many varieties and combinations. You must experiment with these various types of leads until you became comfortable with them.

\footnotetext{
${ }^{1}$ Ibid.

${ }^{2}$ Ibid. 69.
} 


\section{Anecdotal Lead}

The anecdotal lead. is the most popular among nonfiction writers. It is also the easiest kind to write. It is usually a story about an individual which illustrates some general remarks made later in the article. This kind of lead is good for articles without dramatic content. The anecdotal lead makes the article "feel less like required reading in a school textbook."1

\section{statement Lead}

This type of lead is used when you have something startling or unusual to say. The following example illustrates the point." "Some mad scientists have been tampering with the weather. Since the last decade, the weather has gone haywire. . . The globe is on the brink of starvation." The statement lead should be used where it brings surprise.

${ }^{1}$ Ibid.

${ }^{2}$ Ibid., 70 


\section{Prose-Poetry Lead}

The prose-poetry lead "is the hardest kind to write, the least likely to come off successfully." l Below is an example of this kind of a lead. Max Gunther needed a lead in an article which described man's expanding knowledge of the universe. The prose-poetry lead ran as follows:

In a near infinity of burning stars and black space so enormous that it absolutely cannot be imagined, on a speck of rock so small that to mention it seems almost ridiculous, tiny creatures called men are trying to find out where they are. ${ }^{2}$

The lead says what the article is all about and also gives the reader the writer's emotional view. ${ }^{3}$

\section{News Article Leads}

Writing the lead for a news article requires special skill. When writing a news article, the lead must answer at least four of the following six questions: (1) Who is it?
(2) What happened?
(3) Where did it occur?
(4) When did it take place? (5) Why did it happen? (6) How did it happen?" The most important question should be answered first. Below are different types of leads for news articles.

\footnotetext{
${ }^{1}$ Ibid. , 71 .

${ }^{2}$ Ibid.

${ }^{3}$ Ibid.

${ }^{4}$ Reyes, 19 .
} 


\section{Summary Lead}

This lead begins by summarizing vital news facts.

Example: "Nelson Mandela was released from prison yesterday, opening the door to a negotiated settlement in South Africa."

\section{Question Lead}

This lead asks a question that is currently important to many people in the audience.

Example: "Will Bill Clinton step down if he committed. perjury?"

\section{startling statement}

Many newspapers use this type of a lead to catch their readers' attention. ${ }^{1}$

Example: "The President resigned. Shortly after Kenneth starr made his report public . . ."

\section{Involving the Reader}

A reader who is not actively involved and attracted to the article will probably not receive the article's message. The following literary devices can make the difference between a dull article or one that grabs the reader's attention.

${ }^{1}$ Ibid. , 20-21. 
The "You" Technique

Use the word "you" when writing articles. The "you" could be direct or implied. "By using 'you' as early as possible in the article, and repeating it from time to time, you involve the reader. Result? You get reader identification and participation."1

\section{Stick to the Specifics}

Probably one of the most important rules to follow in writing is sticking to the specific details of the article's topic. It means getting down to facts, people, colors, sensations, sounds. "Great writers concentrate on detail. - . Being a successful writer without being specific is impossible."2 You do it by focusing on what is visible, heard, or measurable. Give names of people, places, and quote what was said. ${ }^{3}$

${ }^{1}$ Stewart Harral, The Feature Writer's Handbook (Oklahoma City, OK: University of Oklahoma Press, 1959), 21.

Ibid., 19.

${ }^{3}$ Ibid. 
Use Active Verbs

Active verbs hold the reader's attention. They also help to shorten sentences. ${ }^{1}$ You must turn passive verbs into active verbs.

\section{Use Dialogue}

The reader wants to hear people conversing. The dialogue must also be going somewhere. To test the effectiveness of your quotation, ask yourself, can you leave it out and still keep the story? If the answer is "Yes," then cut it out. ${ }^{2}$

\section{Mix Fact and Emotion}

You will keep your reader's attention longer if you mix "an idea and an emotion into as many sentences as possible. Example: 'His curiosity piqued, Griffith took ten grams of Melamine, and heated the product on a watch crystal. Then he stared in wonderment'." ${ }^{3}$

\section{Use Contrasts}

The world is full of contrasts. There is joy and pain, youth and old age, laughter and weeping. Example: "Ten

\footnotetext{
${ }^{1}$ Ibid.

${ }^{2}$ Ibid. , 22 .

${ }^{3}$ Ibid., 30 .
} 
years ago, Nelson Mandela languished in a tiny prison cell. Today, he is one of the world's greatest leaders."

Use Anecdotes

Stuart Rose called the anecdote "the life blood of a very good article."1 If you are writing a story about someone, interview the person. Watch the person in his/her daily duties and report small comments about their personal actions and habits in the article. ${ }^{2}$

\section{Show the Story}

Do not tell the readers what happened, show it. Instead of writing, "He was angry," say "He slammed the door and stormed out."

\section{Detail the Character}

If you are writing a biographical article, your readers want to know what the person looks like. What is the person's age? What kind of clothes is the person wearing? All these details help the reader to see the character.

IIbid., 32.

${ }^{2}$ Ibid. 


\section{Editing Your Article}

You, the writer, are the best editor of your article. You know exactly what you want to say. With constant practice, you can improve your manuscript. The following suggestions are guidelines to help you edit your manuscript.

1. Make sure your manuscript tells one story or makes one point.

2. Target the manuscript towards one primary audience. One editor lamented that "a promising manuscript about elderly people seemed addressed to four different audiences, the elderly themselves, their children who were middle-aged adults, ministries for elderly people, and churches in general."1

3. Show the readers how they will benefit from your story or article. "A book or article should not promise to solve the world's population crisis while eliminating teenage unemployment and educating all nonliterate people."2

4. Use subheadings to keep the reader on track.

5. Make sure that every section, paragraph, sentence, and word is necessary. Economize with words as you do with money. Do not say it in five words if you can in three.

"Editorial Check Points," Interlit Imprint, unit 12 , 1996, 14.

${ }^{2}$ Ibid. 
6. Check all the facts. Does the person's age match date of birth? Are all the dates correct?

7. Check every sentence. Make sure the language is simple. The sentences should also be short. "The American Press Institute made surveys of the relationship between sentence length and reader comprehension. One newspaper with an average of 17 words in its sentences had a reader comprehension of $97 \%$. Another with an average sentence of 33 words had comprehension of only $31 \% . " 1$

8. Use active verbs. "(a) Identify the action in every sentence. (b) Put action in the verb. (c) Find out what or who did the action. (d) Put the subject close to the verb." 2

\section{Conclusion}

The guidelines in this appendix are not exhaustive. Read as many books on writing as you can. Finally, write. If you want to develop your writing skills, practice every day. The old adage says, "Writing requires an application of a coat of glue to the seat of the chair."

${ }^{1}$ Kendall Wingrave, "Ten Commandments for Copy Editors," Interlit Imprint, unit 17, 1996, 20-21.

2 "Make Sentences Move," Interlit Imprint, unit 17, 1996,32 . 


\section{BIBLIOGRAPHY}

Adeney, Miriam. "Writer Training: God Gives the Increase." Interlit, April 1997, 12.

Barnhart, Helen S. "Writing the How To Article." In Handbook of Magazine Article Writing; ed. Jean Fredette, 184. Cincinnati: Writer's Digest Books, 1990.

Bascom, Tim. "Literature with Clout." Interlit, March 1991, 2 .

. "Thought Crimes." Interlit Imprint, unit 13, 1996,

Brook, Larry. "Learn by Doing." Interlit Imprint, unit 16, $1996,23$.

"Comment." Financial Gazette, 26 February 1998, 20.

Costa, Charlie. "Editorial Traits That Build Writers." Interlit Imprint, unit 13, 1996, 6-7.

Darmani, Lawrence. "Step Leaps onto Ghana." Interlit, March 1991,12 .

Drucker, Peter F. Management: Tasks, Responsibilities, Practices. New York: Harper and Row, 1985.

"Editorial Check Points." Interlit Imprint, unit 12, 1995, 14 .

Editors of the Harvard Post. How to Produce a Small

Newspaper. N.p.: Harvard Common Press, 1978.

Espy, Siri. Marketing Strategies for Non-Profit Organizations. Chicago: Lyceum Books, 1993.

Flanagan, Joan. The Grass Roots Fund-Raising Book. Chicago: Contemporary Books, 1982. 
George, Carl F., and Robert E. Logan. Leading and Managing Your Church. Grand Rapids, MI: Fleming H. Revell, 1992.

Gilmore, Alec. "Publish for Profit." Interlit, March 1996, 4 .

Gunther, Max. Writing the Modern Magazine Article. Boston: The Writer Inc., Publishers, 1968.

Harral, Stewart. The Feature Writer's Handbook. Oklahoma City, OK: University of Oklahoma Press, 1959.

Hasling, John. The Audience, the Message, the Speaker. New York: McGraw-Hill Book Co., 1976.

Hesselgrave, David J., and Edward Rommen. Contextualization. Grand Rapids, MI: Baker Book House, 1992.

"High Interest Rates Hit Property Market." The Herald, 22 October 1998,5 .

Horne, Richard. "Three A's for Reader Retention." Imprint, unit $4,1994,24-25$.

Hunter, George Y., III. How to Reach Secular People. Nashville: Abingdon Press, 1992.

"Interact for Impact." Interlit Imprint, unit 16, 1996, 21.

Lai, Linda. "Writer Training." Interlit, September 1989, 18.

Larson, Charles U. Persuasion Reception and Receptability. Boston: Wordsworth Publishing Company, 1995.

Lieberman Research. How and Why People Buy Magazines. New York: Publisher's Clearing House, 1977.

Lindemann, Erica. A Rhetoric for Writing Teachers. Oxford: Oxford University Press, 1995.

Lucas, Stephen E. The Art of Public Speaking. New York: Random House, 1989.

Lwanga, Martin. "Making a Magazine Succeed." Interlit, December 1995, 18.

Makay, John. Public Speaking. Philadelphia: Harcourt, Brace \& Jovanovich College Pub., 1992. 
"Make Sentences Move." Interlit Imprint, unit 17, 1996, 32.

Martinelli, Mario Paulo. "Marketing strategies for Seventhday Adventist Literature in Brazil." D.Min. dissertation, Andrews University, 1996.

Mbuggus. "Hunting for Talent in Kenya." Media Focus, January $1999,15$.

McKenna, Regis. Relationship Marketing. New York: EddisonWembly Pub. Co., 1991.

Miller, Kevin. "To Market a Magazine." Interlit Imprint, unit $12,1995,3-5$.

Miller, Susan. "How Many Readers Do You Have?" Interlit Imprint, unit 1, 1994, 2 .

Minnick, Wayne C. The Art of Persuasion. Boston: Houghton Mifflin Co., 1968.

Mureu, Simon K. "Writing Is Not Only for the Educated." Interlit, september 1995, 18.

"A New Magazine Is Launched." Financial Gazette, 14 May 1998,1 .

Niemeyer, Larry. "The Information Super Highway and Christian Response to Knowledge." Perspectives, January $1998,47$.

Njoroge, Mwaura. "Distribution That Works." Interlit, June $1995,18$.

. "Involve Your Reader." Interlit, June 1989, 12.

Oasterhoff, Rhonda. "Designer Knots." Interlit Imprint, unit $1,1994,30$.

Phiri, Isaac. "Editors Are Good Neighbors." Interlit Imprint, unit 13, 1996, 19.

Reyes, Rex C. Writing Tips. Manila, Philippines: OMF Literature, 1993.

Scholl, Steven. "Design: Its Importance in Marketing." Interlit, June 1995, 19. 
Seventh-day Adventist Bible Encyclopedia. Vol. 10. Washington, DC: Review and Herald Pub. Assn., 1976. S.v. "Publishing Department," "South Africa."

Smith, Donald K. Creating Understanding. Grand Rapids, MI: Zondervan Publishing House, 1992.

"The Spectrum of Training." Interlit Imprint, unit 16, 1996, 24.

Taylor, Larry. "Organize a Writers' Workshop." Interlit, March 1995, 15.

Ulanov, Barry. "The Relevance of Rhetoric." In Rhetoric and Composition, ed. Richard L. Graves. Rochelle Park, NJ : Hayden Book Company, 1984.

Vision for Self-Sufficient Publishing. Colorado Springs, Co: Cook Communication Ministry, 1996.

Wachira, Horon. "Can Anyone Be a Writer?" Interlit, September 1993, 15.

. "Thoughts on Publishing a Magazine." Interlit, March 1986, 13.

Warren, Rick. The Purpose-Driven Church. Grand Rapids, MI: Zondervan Publishing House, 1995.

Webster, Eric. "Editorial." Signs of the Times, January 1986 .

. "Editorial." Signs of the Times, December 1989. . "Editorial." Signs of the Times, January 1991.

White, Ellen G. Counsels to Writers and Editors. Nashville, TN: Southern Publishing Assn., n.d.

- Life Sketches. Mountain View, CA: Pacific Press Publishing Assn., 1915.

Wingrave, Kendall. "Ten Commandments for Copy Editors." Interlit Imprint, unit 17, 1996, 20-21.

Wolseley, Roland. "Why Magazines Fail." Interlit, March 1984,8 . 
Youngberg, John, and Millie Youngberg. Family Life at Its Best. Unpublished manuscript, introduction.

Zannes, Estelle. Communication: The Widening Circle. Reading, MA: Addison, Wesley Pub. Co., 1982. 